\title{
Abstracts voorjaarsvergadering NVU, 16 en 17 mei 2019, Rotterdam
}

\section{Vergelijking van complicaties van drie technieken van MRI-gerichte prostaatbiopten (FUTURE trial)}

O. Wegelin, L. Exterkate, M. van der Leest, J.C. Kelder,

J.L.H.R. Bosch, J.O. Barentsz, D.M. Somford en

H.H.E. van Melick

St. Antonius Ziekenhuis, Nieuwegein

\section{Introductie}

De FUTURE trial is een multicenter RCT naar MRI target biopten (TB's) bij patiënten met negatieve systematische biopten (SB's) en een verdenking op prostaatkanker. In deze analyse werden adverse events (AE) van drie technieken van TB vergeleken.

\section{Methoden}

234 patiënten met PIRADS-laesies $\geq 3$ op mpMRI werden 1:1:1 gerandomiseerd voor één TB-techniek: 77 voor transrectale in-bore MRI (MRI-TB), 79 voor transperineale MRI/TRUS fusie (FUS-TB) en 78 voor transrectale cognitieve fusie (COG-TB). Bij FUS-TB en COG-TB werden na TB's herhaalde SB's afgenomen. Baseline, MRI en procedurele uitkomsten werden vergeleken. De 30 dagen postbiopsie AE's (Clavien-Dindo) werden vergeleken. Er werd een univariaat analyse uitgevoerd voor het aantal afgenomen biopten, benadering (transrectaal vs. transperineaal) en gebruik van anticoagulantia.

\section{Resultaten}

Er waren geen verschillen in baselinekarakteristieken en MRI-uitkomsten tussen de groepen. Het mediaan aantal afgenomen biopten was significant verschillend MRI-TB 2, FUS-TB 14 en COG-TB $13(p<0,001)$. Graad 1 en 2 AE's traden respectievelijk in $64 \%$ en $6 \%$ van de gevallen op binnen het gehele cohort. De meest voorkomende AE's waren hematurie (53\%) en hematospermie (37\%). In totaal trad bij $3,4 \%$ van de patiënten een UWI op.

Er was een significant verschil in AE's (graad 1 of 2) tussen de groepen; $53 \%$ bij MRI-TB, $71 \%$ bij FUS-TB en $85 \%$ bij COG-TB $(p<0,001)$. Er was een associatie tussen het aantal afgenomen biopten en het optreden van AE's $(\mathrm{OR}=1,11$ per extra biopt; 95\%-BI $=1,06-1,17(p<0,001))$. Gebruik van anticoagulantia was niet geassocieerd met bloedingscomplicaties $(\mathrm{OR}=1,24 ; 95 \%-\mathrm{BI}=0,66-2,35(p=0,51))$. Transrectale biopten hadden een verhoogd risico op AE's vergeleken met transperineale biopten $(\mathrm{OR}=2,54 ; 95 \%$-BI $=1,16-5,77(p<0,05))$.

\section{Conclusies}

TB is veilig; er traden enkel graad-1- en 2-AE's op, die met name bestonden uit hematurie en hematospermie. Er is een associatie tussen het aantal afgenomen biopten en het optreden van AE's. MRI-TB heeft minder graad-1- en 2-AE's vergeleken met FUS-TB en COG-TB, waarschijnlijk als gevolg van het achterwege laten van SB bij MRI-TB. Transrectale biopten geven een verhoogd risico op AE's vergeleken met transperineale biopten (tabel 1.1).

$凶$ Prof. dr. Peter F.A. Mulders

peter.mulders@radboudumc.nl

Radboudumc, Nijmegen, Nederland

Tijdschrift voor Urologie,

Bohn Stafleu van Loghum, Houten, Nederland 
Tabel 1.1 Adverse events van drie groepen TB's

\begin{tabular}{|c|c|c|c|c|}
\hline & $\begin{array}{l}\text { MRI-TB } \\
(n=77)\end{array}$ & $\begin{array}{l}\text { FUS-TB } \\
(n=79)\end{array}$ & $\begin{array}{l}\text { COG-TB } \\
(n=78)\end{array}$ & \\
\hline Clavien-Dindo-graad: & & & & $p<0,001$ \\
\hline geen adverse events & $47,4 \%(36)$ & $29,1 \%(23)$ & $15,4 \%(12)$ & \\
\hline $\operatorname{graad} 1$ & $50,0 \%(38)$ & $65,8 \%(52)$ & $74,4 \%(58)$ & \\
\hline $\operatorname{graad} 2$ & $2,6 \%(2)$ & $5,1 \%(4)$ & $10,3 \%(8)$ & \\
\hline $\operatorname{graad} 3,4,5$ & - & - & - & \\
\hline hematurie & $35,5 \%(27)$ & $50,6 \%(40)$ & $74,4 \%(58)$ & $p<0,001$ \\
\hline hematospermie & $26,3 \%(20)$ & $35,4 \%(28)$ & $50,0 \%(39)$ & $p<0,01$ \\
\hline rectaal bloedverlies & $2,6 \%(2)$ & $2,5 \%(2)$ & $5,1 \%(4)$ & $p=0,59$ \\
\hline koorts & $1,3 \%(1)$ & $2,5 \%(2)$ & $5,1 \%(4)$ & $p=0,46$ \\
\hline UWI & $2,6 \%(2)$ & $1,3 \%(1)$ & $6,4 \%(5)$ & $p=0,21$ \\
\hline retentieblaas & - & $3,8 \%(3)$ & $5,1 \%(4)$ & $p=0,15$ \\
\hline hematoom & - & $3,8 \%(3)$ & - & $p=0,29$ \\
\hline overige: & & & & $p=0,56$ \\
\hline lage rug pijn & $1,3 \%(1)$ & $1,3 \%(1)$ & - & \\
\hline atriumfibrilleren & - & $1,3 \%(1)$ & - & \\
\hline
\end{tabular}

\section{Zijn er modificeerbare factoren gerelateerd aan urethraplastiekcomplicaties na de tubularized incised urethral plate procedure bij distale en midschacht hypospadie? Analyse van de Nederlandse Hypospadie Studie}

F. van der Toorn, P.R. Callewaert, R.P. de Gier, E.H. van der Horst, M.G. Steffens, F.M.J.A. Froeling, R.P.J. Schroeder, J.S.L.T. Quadackers, M. Wildhagen, S. Remmers, G.M.A. Beckers, M.J. Roobol en K.P. Wolffenbuttel Sophia Kinderziekenhuis, Erasmus MC, Rotterdam

\section{Introductie}

Om de kwaliteit van hypospadiechirurgie te meten en zo mogelijk te verbeteren, is in 2009 gestart met de (prospectieve en multicenter) Nederlandse Hypospadie Studie. Een belangrijke uitkomst is het optreden van urethraplastiekcomplicaties (UC). Dit is een verzamelnaam voor de complicaties fistel, dehiscentie, meatusstenose, urethrastenose en urethradivertikel. Het doel van huidig onderzoek is om de korte termijn (i.e. 6 maanden na operatie) UC vast te stellen na een tubularized incised urethral plate (TIP) procedure in de groep patiënten met een distale of midschacht hypospadie. Daarnaast werd gekeken of er modificeerbare prognostische factoren ten aanzien van UC konden worden geïdentificeerd.

\section{Materiaal en methoden}

Van de 1034 evalueerbare patiënten met een distale of midschacht hypospadie, ondergingen 703 patiënten (68\%) een TIP-procedure. Een excisie van het afwijkende preputium werd bij 547 patiënten (78\%) verricht en een preputiumreconstructie bij 156 patiënten (22\%). Eventuele complicaties werden in de online database geregistreerd bij de postoperatieve controle na zes maanden. Een multivariate multilevel analyse (met random intercept voor operateur en correctie voor de invloed van positie van de meatus en divisie van het corpus spongiosum) werd uitgevoerd om de voorspellende waarde van de modificeerbare factoren ten aanzien van $\mathrm{UC}$ te bepalen.

\section{Resultaten}

Bij 23,8\% van de 703 patiënten trad een UC op, te weten: fistel $11,4 \%$, dehiscentie $13,4 \%$ en meatusstenose $0,9 \%$. In de groep operateurs met $n>20$ varieerde de UC-rate tussen de $3 \%$ en $49 \%$. Multivariate multilevel analyse (tabel 2.1 ) geeft aan dat de subepitheliale hechttechniek van de urethraplastiek een kleinere kans geeft op UC $(2,22$ keer minder) dan de transepitheliale hechttechniek. Ook preputiumreconstructie geeft een kleiner risico op UC (2,5 keer minder) dan preputiumexcisie.

\section{Conclusie}

Urethraplastiekcomplicaties na TIP-procedures voor distale of midschacht hypospadie treden relatief vaak op, met een duidelijke variatie in frequentie tussen de operateurs. De geidentificeerde prognostische factoren kunnen zo nodig als handvatten dienen om desgewenst de operatietechniek aan te passen. 
Tabel 2.1

\begin{tabular}{|c|c|c|c|c|}
\hline & coëfficiënt & odds ratio & $95 \%-B I$ & $p$-waarde \\
\hline (Intercept) & $-1,09$ & & & 0,111 \\
\hline \multicolumn{5}{|l|}{ hypospadieclassificatie: } \\
\hline meatus coronair/distale schacht - DCS distale schacht & ref & & & \\
\hline meatus coronair/distale schacht - DCS midschacht & 0,37 & 1,45 & $(0,88-2,4)$ & 0,142 \\
\hline meatus coronair/distale schacht - DCS proximale schacht & 2,73 & 15,30 & $(4,28-55,74)$ & 0,000 \\
\hline meatus midschacht - DCS midschacht & 0,86 & 2,37 & $(1,09-5,15)$ & 0,029 \\
\hline meatus midschacht - DCS proximale schacht & 1,47 & 4,34 & $(1,44-13,04)$ & 0,009 \\
\hline \multicolumn{5}{|l|}{ modificeerbare factoren met $p<0,05$ in univariate analyse: } \\
\hline \multicolumn{5}{|l|}{ leeftijd gecategoriseerd: } \\
\hline$\leq 12$ maanden & ref & & & \\
\hline$>12$ maanden & 0,28 & 1,32 & $(0,45-3,87)$ & 0,612 \\
\hline \multicolumn{5}{|l|}{ diameter urethraplastiek en splint: } \\
\hline urethraplastiek $>$ Ch10 of 12 en splint Ch 10 of 12 & ref & & & \\
\hline urethraplastiek $>$ Ch10 of 12 en splint $\mathrm{Ch} 6$ of 8 & $-0,55$ & 0,58 & $(0,18-1,87)$ & 0,359 \\
\hline urethraplastiek $>$ Ch 6 of 8 en splint $\mathrm{Ch} 6$ of 8 & $-0,80$ & 0,45 & $(0,15-1,32)$ & 0,145 \\
\hline \multicolumn{5}{|l|}{ interactie tussen leeftijd, gecategoriseerd met plastiek en splint: } \\
\hline \multicolumn{5}{|l|}{ leeftijd $>12 \mathrm{mnd}+$ urethraplastiek $>$ Ch10 of 12 en splint Ch10 of 12} \\
\hline leeftijd $>12 \mathrm{mnd}+$ urethraplastiek $>$ Ch10 of 12 en splint $\mathrm{Ch} 6$ of 8 & $-0,46$ & 0,63 & $(0,15-2,75)$ & 0,542 \\
\hline leeftijd $>12 \mathrm{mnd}+$ urethraplastiek $>$ Ch 6 of 8 en splint $\mathrm{Ch} 6$ of 8 & $-0,32$ & 0,73 & $(0,21-2,52)$ & 0,615 \\
\hline blaasdrainageduur & 0,08 & 1,08 & $(0,94-1,25)$ & 0,291 \\
\hline \multicolumn{5}{|l|}{ hechttechniek urethraplastiek: } \\
\hline doorlopend & ref & & & \\
\hline geknoopt & 0,73 & 2,07 & $(0,92-4,67)$ & 0,081 \\
\hline \multicolumn{5}{|l|}{ hechttechnie urethraplastiek: } \\
\hline transepitheliaal & ref & & & \\
\hline subepitheliaal & $-0,81$ & 0,45 & $(0,25-0,8)$ & $\mathbf{0 , 0 0 7}$ \\
\hline \multicolumn{5}{|l|}{ preputium: } \\
\hline preputium excisie & ref & & & \\
\hline preputium reconstructie & $-0,92$ & 0,40 & $(0,21-0,76)$ & $\mathbf{0 , 0 0 5}$ \\
\hline
\end{tabular}

Modificeerbare factoren met $p>0,05$ in univariate analyse: gewicht, androgeenmedicatie, antibiotica perioperatief, optische vergroting, operatieduur, weefselischemie (type/duur), hechtmateriaal urethraplastiek, type interpositielaag, verband (type/duur), blaaskatheter/splint (type/duur), opnameduur.

$D C S$ divisie corpus spongiosum.

\section{PSA-testen bij mannen ouder dan 70 jaar: zwart-wit of toch grijs?}

M.J. Roobol en S. Remmers

Erasmus Universiteit Medisch Centrum, Rotterdam

\section{Introductie}

Prostaatkankerscreening op basis van het PSA bij mannen ouder dan 70 jaar wordt in de meeste richtlijnen afgeraden vanwege het risico op overdiagnostiek. In deze studie beschrijven we meerjarige follow-up van Nederlandse mannen die eenmalig meededen aan een internationale gerandomiseerde screeningsstudie.

\section{Materiaal en methoden}

Mannen (70 tot en met 74 jaar), die waren geloot in de inter- 
cer bohn

9) stafleu

van loghum

bohn

stafleu

van loghum

bohn

stafleu

- van loghum
CCS bohn
8 stafleu
L van loghum

$\sum\left\{\begin{array}{l}\text { bohn } \\ \text { stafleu } \\ \text { van loghum }\end{array}\right.$ $\int S \begin{aligned} & \text { bohn } \\ & \text { stafleu }\end{aligned}$

van loghum

CSe bohn

Stafleu cef bohn

Ptufleu

van loghum cef bohn

8 stafleu

van loghum cec bohn

stafleu

van loghum

\section{bohn}

stafleu
van loghur

$\int$ bohn

stafleu

van loghum

cCehn bohn

stafleu

CL van loghum

cer bohn

9) stafleu

van loghum

bohn

stafleu

van loghum

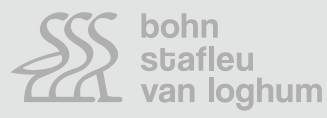

CCS bohn

stafleu

van loghum

\section{gedru}

een

SSS $\begin{aligned} & \text { bohn } \\ & \text { stafleu }\end{aligned}$

van loghum

$\int S \int \begin{aligned} & \text { bohn } \\ & \text { stafleu } \\ & \text { van logh }\end{aligned}$

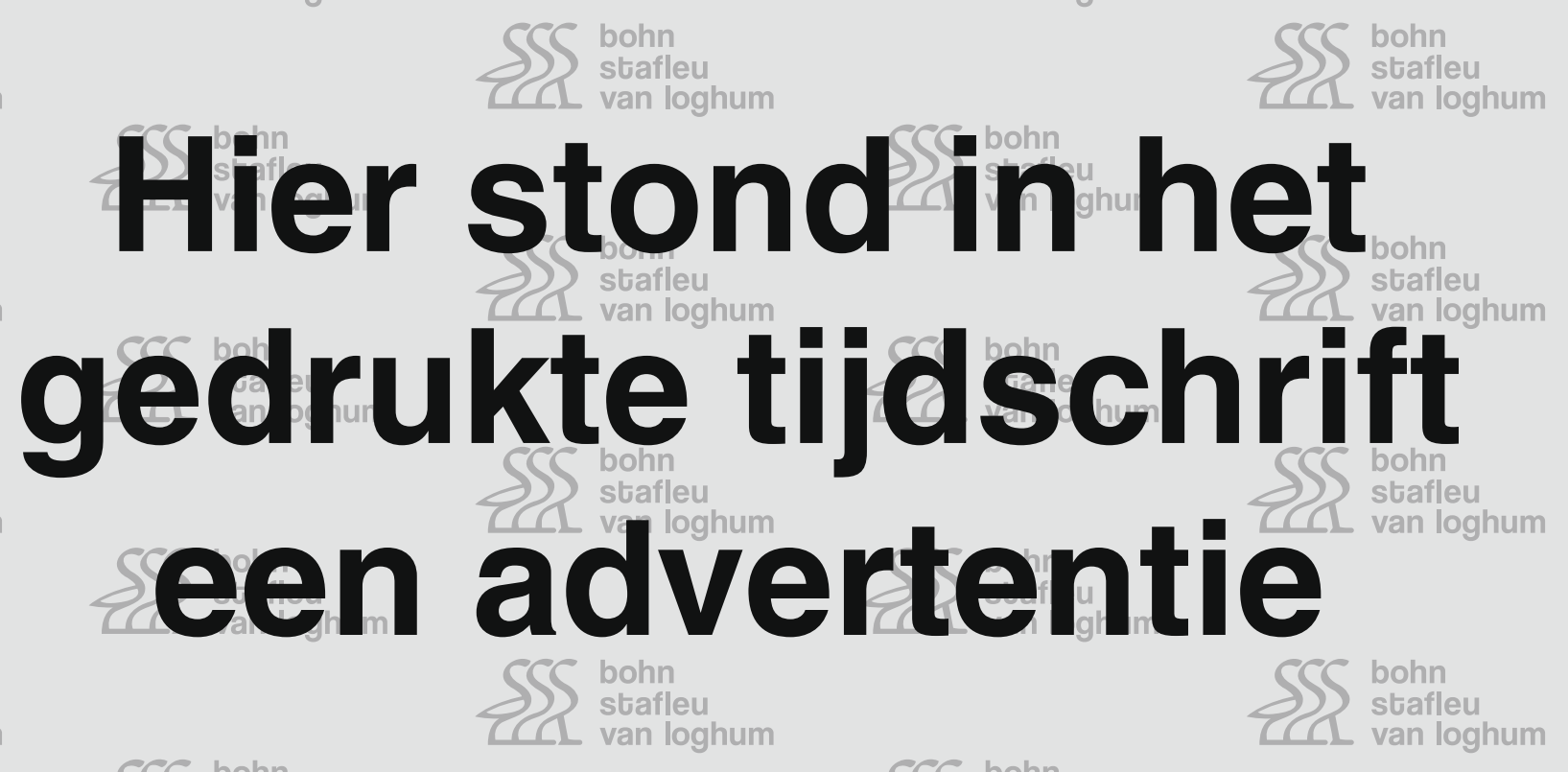

cef bohn

stafleu

van loghum

CSS bohn

stafleu

van loghum

SCS bohn

8 stafleu

van loghum

SSS bohn

van loghum

CSe bohn

8 stafleu

L van loghum

$\iint \begin{aligned} & \text { bohn } \\ & \text { stafleu }\end{aligned}$

van loghum

SSS bohn

van loghum

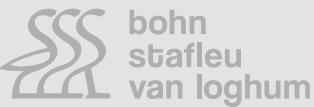

SSS bohn

van loghum

SCS bohn

S) stafleu

1 . van loghum

CCS bohn

bohn
stafleu

CL van loghum van loghum

SS bohn

SS stafleu

SSS $\begin{aligned} & \text { bohn } \\ & \text { stafleu } \\ & \text { van }\end{aligned}$

van loghum

SSS $\begin{aligned} & \text { bohn } \\ & \text { stafleu } \\ & \text { van loghur }\end{aligned}$

van loghum

SCS bohn

$\iint$ stafleu

L van loghum

SSS $\begin{aligned} & \text { bohn } \\ & \text { stafleu }\end{aligned}$

(1 van loghum

SSS $\begin{aligned} & \text { bohn } \\ & \text { stafleu } \\ & \text { van }\end{aligned}$

van loghum

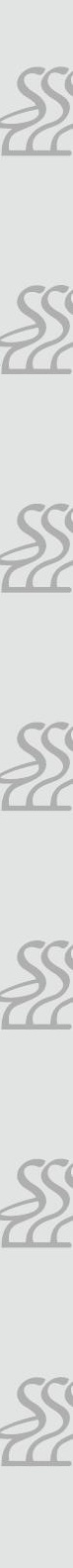

CCS bohn

8) stafleu

van loghum

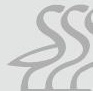

SCS bohn

$9 \int$ strafleu

. van loghum

CSS bohn

$8 \int$ stafleu 
cer bohn

9) stafleu

van loghum

bohn

stafleu

van loghum

bohn

stafleu

- van loghum
CCS bohn
8 stafleu
L van loghum

$\sum\left\{\begin{array}{l}\text { bohn } \\ \text { stafleu } \\ \text { van loghum }\end{array}\right.$ $\int S \begin{aligned} & \text { bohn } \\ & \text { stafleu }\end{aligned}$

van loghum

CSe bohn

Stafleu cef bohn

Ptufleu

van loghum cef bohn

8 stafleu

van loghum cec bohn

stafleu

van loghum

\section{bohn}

stafleu
van loghur

$\int$ bohn

stafleu

van loghum

cCehn bohn

stafleu

CL van loghum

cer bohn

9) stafleu

van loghum

bohn

stafleu

van loghum

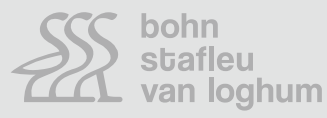

CCS bohn

stafleu

van loghum

\section{gedru}

een

SSS $\begin{aligned} & \text { bohn } \\ & \text { stafleu }\end{aligned}$

van loghum

$\int S \int \begin{aligned} & \text { bohn } \\ & \text { stafleu } \\ & \text { van logh }\end{aligned}$

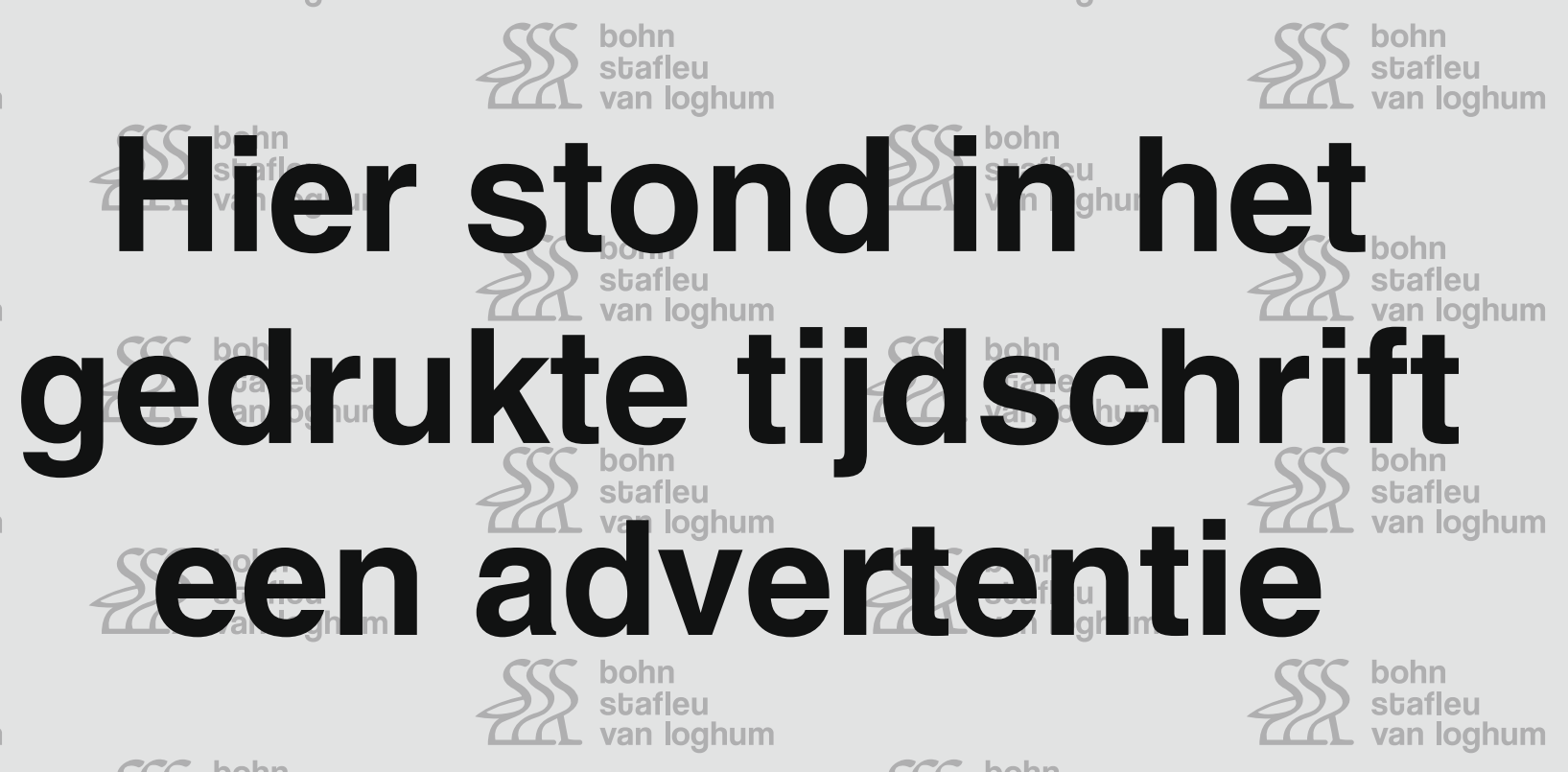

cef bohn

stafleu

van loghum

CSS bohn

stafleu

van loghum

SCS bohn

8 stafleu

van loghum

SSS bohn

van loghum

CSe bohn

8 stafleu

L van loghum

$\iint \begin{aligned} & \text { bohn } \\ & \text { stafleu }\end{aligned}$

van loghum

SSS bohn

van loghum

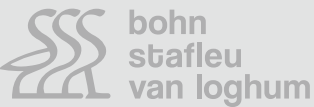

SSS bohn

van loghum

SCS bohn

S) stafleu

1 . van loghum

CCS bohn

bohn
stafleu

CL van loghum van loghum

SS bohn

SS stafleu

SSS $\begin{aligned} & \text { bohn } \\ & \text { stafleu } \\ & \text { van }\end{aligned}$

van loghum

SSS $\begin{aligned} & \text { bohn } \\ & \text { stafleu } \\ & \text { van loghur }\end{aligned}$

van loghum

SCS bohn

$\iint$ stafleu

L van loghum

SSS $\begin{aligned} & \text { bohn } \\ & \text { stafleu }\end{aligned}$

(1 van loghum

SSS $\begin{aligned} & \text { bohn } \\ & \text { stafleu } \\ & \text { van }\end{aligned}$

van loghum

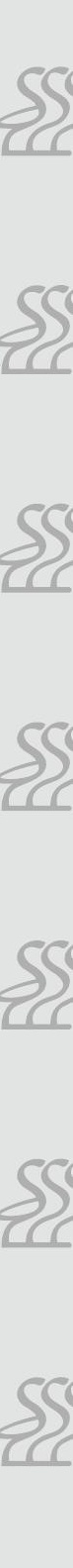

CCS bohn

8) stafleu

van loghum

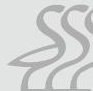

SCS bohn

$9 \int$ strafleu

. van loghum

CSS bohn

$8 \int$ stafleu 
cer bohn

9) stafleu

van loghum

bohn

stafleu

van loghum

bohn

stafleu

- van loghum
CCS bohn
8 stafleu
L van loghum

$\sum\left\{\begin{array}{l}\text { bohn } \\ \text { stafleu } \\ \text { van loghum }\end{array}\right.$ $\int S \begin{aligned} & \text { bohn } \\ & \text { stafleu }\end{aligned}$

van loghum

CSe bohn

Stafleu cef bohn

Ptufleu

van loghum cef bohn

8 stafleu

van loghum cec bohn

stafleu

van loghum

\section{bohn}

stafleu
van loghur

$\int$ bohn

stafleu

van loghum

cCehn bohn

stafleu

CL van loghum

cer bohn

9) stafleu

van loghum

bohn

stafleu

van loghum

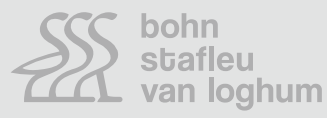

CCS bohn

stafleu

van loghum

\section{gedru}

een

SSS $\begin{aligned} & \text { bohn } \\ & \text { stafleu }\end{aligned}$

van loghum

$\int S \int \begin{aligned} & \text { bohn } \\ & \text { stafleu } \\ & \text { van logh }\end{aligned}$

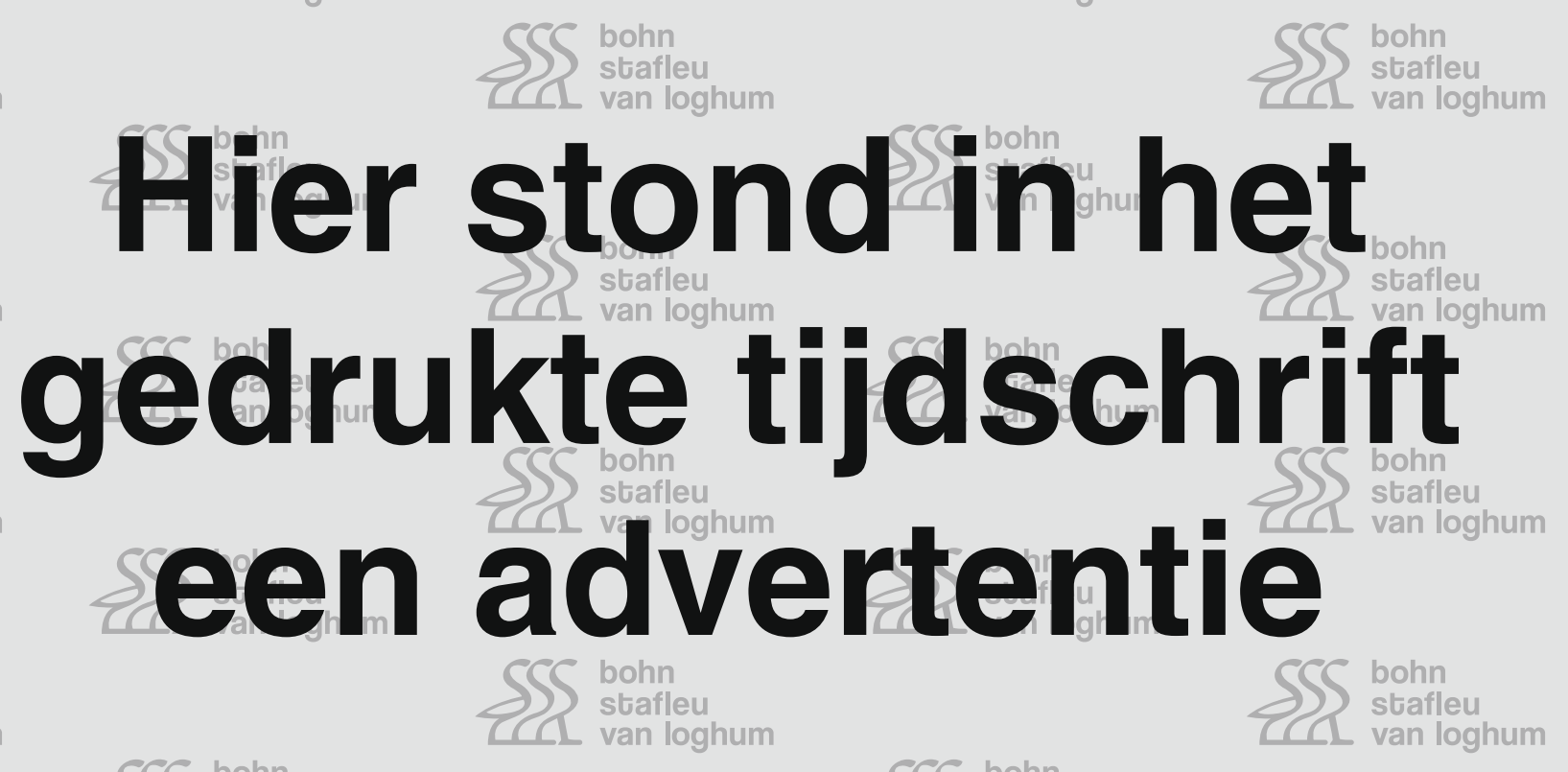

cef bohn

stafleu

van loghum

CSS bohn

stafleu

van loghum

SCS bohn

8 stafleu

van loghum

SSS bohn

van loghum

CSe bohn

8 stafleu

L van loghum

$\iint \begin{aligned} & \text { bohn } \\ & \text { stafleu }\end{aligned}$

van loghum

SSS bohn

van loghum

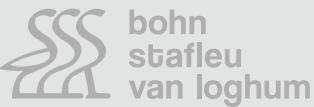

SSS bohn

van loghum

SCS bohn

S) stafleu

1 . van loghum

CCS bohn

bohn
stafleu

CL van loghum van loghum

SS bohn

SS stafleu

SSS $\begin{aligned} & \text { bohn } \\ & \text { stafleu } \\ & \text { van }\end{aligned}$

van loghum

SSS $\begin{aligned} & \text { bohn } \\ & \text { stafleu } \\ & \text { van loghur }\end{aligned}$

van loghum

SCS bohn

$\iint$ stafleu

L van loghum

SSS $\begin{aligned} & \text { bohn } \\ & \text { stafleu }\end{aligned}$

(1 van loghum

SSS $\begin{aligned} & \text { bohn } \\ & \text { stafleu } \\ & \text { van }\end{aligned}$

van loghum

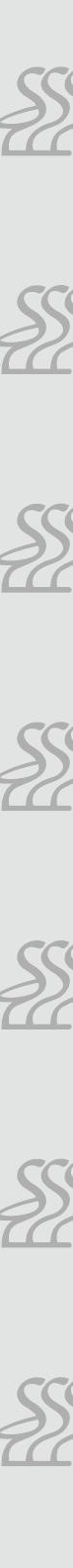

CCS bohn

8) stafleu

van loghum

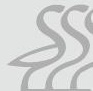

SCS bohn

$9 \int$ strafleu

. van loghum

CSS bohn

$8 \int$ stafleu 
cer bohn

9) stafleu

van loghum

bohn

stafleu

van loghum

bohn

stafleu

- van loghum
CCS bohn
8 stafleu
L van loghum

$\sum\left\{\begin{array}{l}\text { bohn } \\ \text { stafleu } \\ \text { van loghum }\end{array}\right.$ $\int S \begin{aligned} & \text { bohn } \\ & \text { stafleu }\end{aligned}$

van loghum

CSe bohn

Stafleu cef bohn

Ptufleu

van loghum cef bohn

8 stafleu

van loghum cec bohn

stafleu

van loghum

\section{bohn}

stafleu
van loghur

$\int$ bohn

stafleu

van loghum

cCehn bohn

stafleu

CL van loghum

cer bohn

9) stafleu

van loghum

bohn

stafleu

van loghum

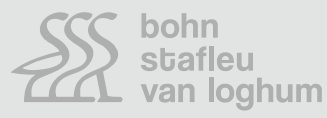

CCS bohn

stafleu

van loghum

\section{gedru}

een

SSS $\begin{aligned} & \text { bohn } \\ & \text { stafleu }\end{aligned}$

van loghum

$\int S \int \begin{aligned} & \text { bohn } \\ & \text { stafleu } \\ & \text { van logh }\end{aligned}$

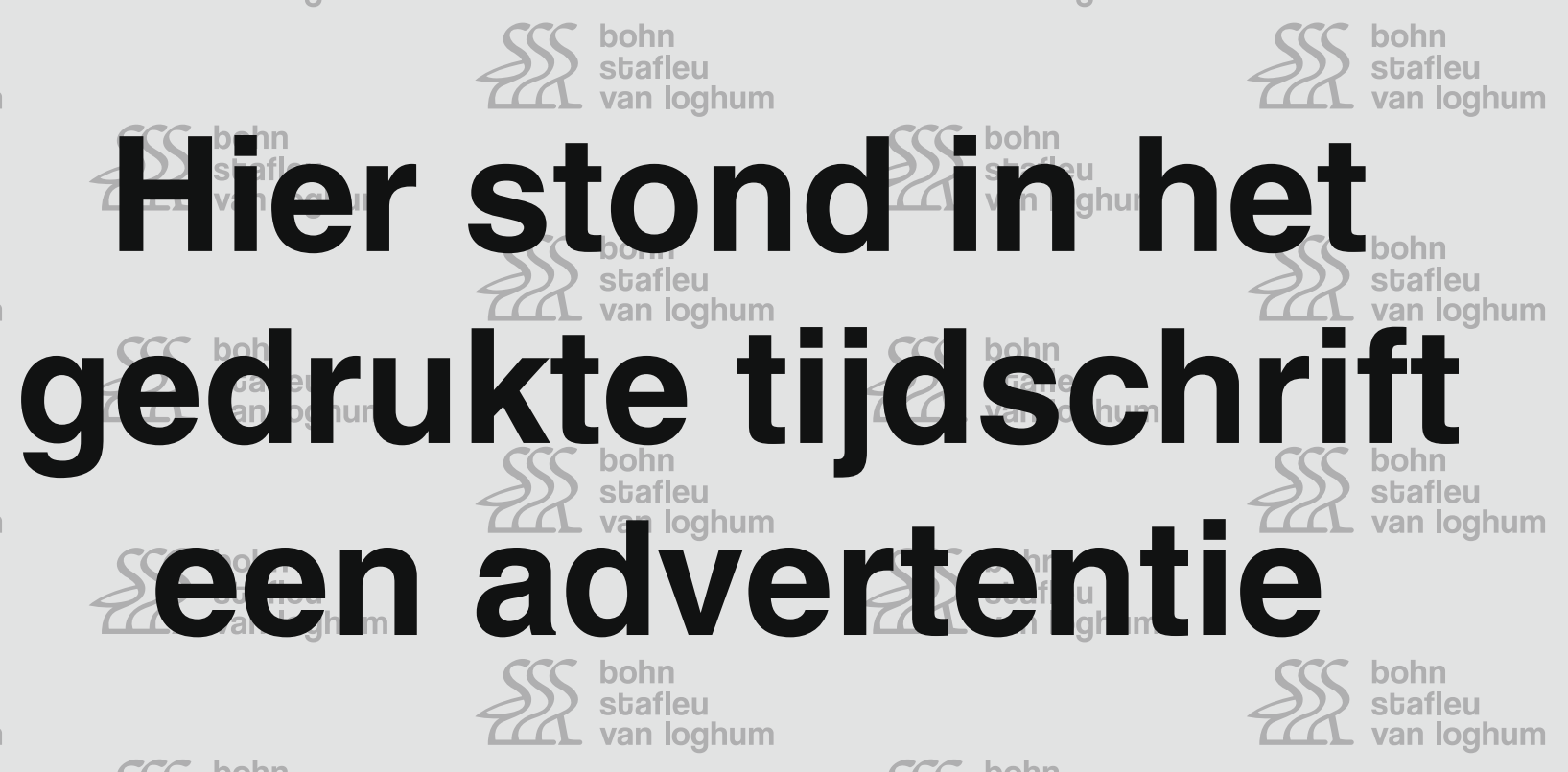

cef bohn

stafleu

van loghum

CSS bohn

stafleu

van loghum

SCS bohn

8 stafleu

van loghum

SSS bohn

van loghum

CSe bohn

8 stafleu

L van loghum

$\iint \begin{aligned} & \text { bohn } \\ & \text { stafleu }\end{aligned}$

van loghum

SSS bohn

van loghum

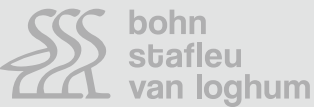

SSS bohn

van loghum

SCS bohn

S) stafleu

1 . van loghum

CCS bohn

bohn
stafleu

CL van loghum van loghum

SS bohn

SS stafleu

SSS $\begin{aligned} & \text { bohn } \\ & \text { stafleu } \\ & \text { van }\end{aligned}$

van loghum

SSS $\begin{aligned} & \text { bohn } \\ & \text { stafleu } \\ & \text { van loghur }\end{aligned}$

van loghum

SCS bohn

$\iint$ stafleu

L van loghum

SSS $\begin{aligned} & \text { bohn } \\ & \text { stafleu }\end{aligned}$

(1 van loghum

SSS $\begin{aligned} & \text { bohn } \\ & \text { stafleu } \\ & \text { van }\end{aligned}$

van loghum

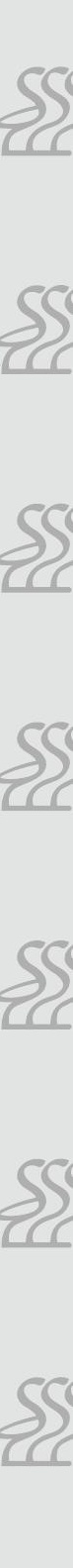

CCS bohn

8) stafleu

van loghum

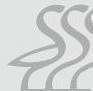

SCS bohn

$9 \int$ strafleu

. van loghum

CSS bohn

$8 \int$ stafleu 
Tabel 3.1

\begin{tabular}{|c|c|c|c|c|c|}
\hline & $n(\%)$ & $\mathrm{PCa}(\%)$ & $\mathrm{csPCa}$ & $\mathrm{M}+/ n$ in $\operatorname{csPCa}$ & $\begin{array}{l}\text { overleden met PCa- } \\
\text { diagnose/PCa-dood (\%) }\end{array}$ \\
\hline \multicolumn{6}{|c|}{ PSA (ng/ml) } \\
\hline$<1,0$ & $770(25 \%)$ & $11(1 \%)$ & $5(45 \%)$ & $3 / 1$ & $11 / 3(27 \%)$ \\
\hline $1,0-1,9$ & $908(30 \%)$ & $37(4 \%)$ & $23(62 \%)$ & $13 / 9$ & 32 / $8(25 \%)$ \\
\hline $2,0-2,9$ & $496(16 \%)$ & $42(8 \%)$ & $19(45 \%)$ & $14 / 9$ & $37 / 12(32 \%)$ \\
\hline $3,0-5,9$ & $571(19 \%)$ & $57(10 \%)$ & $21(37 \%)$ & $10 / 8$ & 47 / $9(21 \%)$ \\
\hline$\geq 6,0$ & $295(10 \%)$ & $55(19 \%)$ & $20(36 \%)$ & $12 / 6$ & $49 / 13(27 \%)$ \\
\hline totaal & 3040 & $202(7 \%)$ & $88(44 \%)$ & $52 / 33$ & $176 / 45(26 \%)$ \\
\hline
\end{tabular}

ventiearm van de studie en niet gediagnosticeerd waren met prostaatcarcinoom ( $\mathrm{PCa}$ ) ten tijde van de screening werden geïncludeerd. Incidentie en mortaliteitsdata over een periode van maximaal 24 jaar worden beschreven. Met een nested casecontrol design en conditionele logistische regressie wordt vastgesteld of PSA ten tijde van screening gerelateerd is aan latere prostaatkankersterfte.

\section{Resultaten}

3040 mannen met een mediane baseline PSA van 1,7 (interkwartielafstand $(\mathrm{IQR})=0,9-3,3) \mathrm{ng} / \mathrm{ml}$ werden geïncludeerd in de analyse. Gedurende follow-up ontwikkelden 202 mannen PCa (7\%), die bij 88 (44\%) mannen met klinisch significant (cs) PCa (Gleason-score $\geq 3+4$ ). De mediane tijd tussen screening en diagnose was 6,3 jaar (IQR 3,7-9,9). Tot nu toe zijn 2586 (85\%) mannen overleden, waarvan $45(2 \%)$ aan PCa met een mediane tijd tussen diagnose en overlijden van 5,3 jaar (IQR = 2,2-10,0) (tabel 3.1). De eerste PSA is voorspellend voor prostaatkankerdood (odds 1,16; 95\%-BI = 1,06-1,26 ( $p=0,001)$ ). Mannen met PSA-levels $<3,0 \mathrm{ng} / \mathrm{ml}$ hebben een lage kans op PCa, maar wel een relatief hoge kans op csPCa. Bij een PSA boven de leeftijdsspecifieke referentie $(\geq 6,0 \mathrm{ng} / \mathrm{ml}, 10 \%$ van de mannen) wordt bijna $20 \%$ geconfronteerd met een PCa-diagnose, die in bijna 30\% van de gevallen een dodelijke afloop heeft.

\section{Conclusie}

Stoppen met PSA-screening kan ondanks de hoge leeftijd toch leiden tot een levensbedreigend PCa. Dit geldt voornamelijk voor mannen met PSA-waarden boven de leeftijdsspecifieke referentie. Dit gegeven moet worden meegenomen in verdere besluitvorming over PSA-testen.

\section{Angst voor terugkeer of progressie van ziekte onder partners van mannen met prostaatkanker}

L.A. Grondhuis Palacios, B.L. den Oudsten, M.E.M. den Ouden,

N.D.M. van Luxemburg, J.J.H. Beck, H. Putter,

R.C.M. Pelger en H.W. Elzevier

Leids Universitair Medisch Centrum, Leiden

\section{Introductie}

Partners ervaren meer angst en emotionele onrust dan patiënten zelf. Het doel van de studie was om te evalueren in hoeverre partners van mannen met prostaatkanker angst ervaren voor terugkeer of progressie van ziekte. Doel was ook om te onderzoeken of er verband bestaat tussen mate van angst en sociodemografische kenmerken, comorbiditeit, klinische kenmerken (PSA, Gleason-score, stadiëring, risicogroep bij gelokaliseerde en lokaal uitgebreide ziekte), type behandeling, jaar van diagnose en type ziekenhuis (perifeer of academisch).

\section{Materiaal en methoden}

Een multicenter, cross-sectionele studie werd verricht onder partners van mannen met prostaatkanker die onder active surveillance vielen, dan wel waren behandeld (na active surveillance) middels prostatectomie, brachytherapie, externe radiotherapie en/of hormoontherapie.

\section{Resultaten}

In totaal deden 322 partners mee. Enige vorm van angst werd door $81,0 \%(n=255)$ ervaren, waarvan $44,4 \%(n=$ 140) matig tot ernstige angst. Sociodemografische kenmerken en comorbiditeit van zowel patiënt als partner waren niet significant met elkaar verbonden, en evenmin was dat het geval voor het jaar van diagnose en type ziekenhuis. Bijna de helft van de partners $(44,6 \%, n=110)$ van wie de man in opzet curatief behandeld was, ervaarde enige vorm van angst. Dertien van de 32 partners $(40,6 \%)$ van mannen onder active surveillance ervaarden matig tot ernstige angst. Hoog PSA $(p<0,001)$, hoge Gleason-score $(p<0,001)$ en 
gemetastaseerde ziekte $(p<0,001)$ zijn significant verbonden met meer angst.

\section{Conclusie}

Ondanks in opzet curatieve behandeling, ervaart bijna de helft van de partners angst voor terugkeer of progressie van ziekte. Partners van mannen onder active surveillance ervaren evenveel angst als partners van mannen die behandeld zijn voor gelokaliseerde ziekte. Zodoende kan geconcludeerd worden dat behandeling bij de optie van active surveillance angst onder partners niet altijd wegneemt. Derhalve is informatievoorziening en communicatie essentieel, waarbij de oncologieverpleegkundige een belangrijke rol speelt.

\section{TURP ten tijde van cystolithotripsie? Een urologisch adagium onder de loep}

\author{
S.L. Mekke, P. van Zanten, L. Grondhuis Palacios, J. Egberts, \\ N. Hendriks, M.J.J. Wijffelman, W.C.G.Zonneveld, \\ S.J. van Loopik, B. Merks, H. Roshani en K.T. Buddingh \\ Haga Ziekenhuis, Den Haag
}

\section{Introductie}

Vaak wordt geadviseerd om ten tijde van een cystolithotripsie ook een transurethrale resectie van de prostaat (TURP) te verrichten om recidiefblaasstenen te voorkomen. Er zijn echter aanwijzingen dat ook zonder gelijktijdige TURP het percentage recidieven klein is. Dit was aanleiding om in onze regio de vijfjaarsuitkomsten te evalueren van patiënten die een cystolithotripsie ondergingen met of zonder TURP.

\section{Methode}

Dit was een multicenter retrospectief onderzoek naar alle mannen die een cystolithotripsie met of zonder TURP ondergingen in de periode januari $2009 \mathrm{t} / \mathrm{m}$ december 2013. Exclusiecriteria waren neurogene blaas, urethrastricturen, een eerdere TURP, eerdere lithotripsie en katheterafhankelijkheid. Primaire uitkomstmaat was een re-cystolithotripsie. Secundaire uitkomstmaten waren een (re)TURP en een urineretentie.

\section{Resultaten}

In vier centra ondergingen in totaal 35 patiënten een cystolithotripsie met TURP en 80 patiënten zonder TURP. Gemiddelde follow-up was 55 maanden. Een re-cystolithotripsie werd verricht bij twee (6\%) patiënten met initiële TURP versus $16(20 \%)$ patiënten zonder TURP $(\mathrm{OR}=0,25$; 95\%$\mathrm{BI}=0,04-1,0(p=0,05))$. Gemiddelde tijd tot re-cystolithotripsie was 39 maanden. Van de patiënten met TURP ontwikkelden er vijf (14\%) een urineretentie versus 17 $(21 \%)$ in de groep zonder TURP $(p=0,40)$. Een (re)TURP in tweede instantie werd verricht bij zes (17\%) van de patienten met initiële TURP versus $13(16 \%)$ in de groep zonder $\operatorname{TURP}(p=0,89)$.

\section{Conclusie}

Een TURP ten tijde van cystolithotripsie lijkt een beschermend effect te hebben op recidief blaasstenen. Een relatief klein aantal patiënten leidde in onze serie echter tot een wijd betrouwbaarheidsinterval. Circa $80 \%$ van de patiënten die geen TURP ondergaat tijdens de cystolithotripsie blijft op middellange termijn vrij van een recidief. De ingreep cystolithotripsie met of zonder TURP leent zich bij uitstek voor gezamenlijke besluitvorming met de patiënt.

\section{Pre- of periablatieve biopsieën: een vergelijking van verschillende diagnostische strategieën bij niertumoren die zijn behandeld middels ablatie}

\author{
C.V. Widdershoven, B.M. Aarts, P.J. Zondervan, B.W. Lagerveld, \\ E.G. Klompenhouwer, A.D. Montauban van Swijndregt, \\ O.M. van Delden, M.M.E.L. Henderickx, R.J.A. van Moorselaar \\ en A. Bex \\ Amsterdam UMC, Amsterdam
}

\section{Introductie}

Het doel van deze studie was in T1-niertumoren het verschil van biopsiestrategie (pre- $v s$. periablatief) weer te geven.

\section{Methode}

Er werd een retrospectieve, multicenterstudie verricht bij patiënten met een T1-niertumor, die was behandeld middels cryo-, microgolf-, of radiofrequente ablatie in de periode 2007-2017 (2 centra) of 2007-2018 (1 centrum) binnen het Nierkankernetwerk Amsterdam. Er werden data verzameld over het geslacht, de leeftijd, het jaar van behandeling, de biopsiestrategie (pre- of periablatief) en complicaties van de biopsie. Pathologische beoordeling werd bekeken voor histologie en Fuhrman-graad. Voor het verschil tussen de twee biopsiestrategieën werd een chikwadraat exacttest verricht.

\section{Resultaten}

Bij de 659 patiënten werden 99 (15,0\%) preablatieve biopsieën en $445(65,1 \%)$ periablatieve biopsieën uitgevoerd. Bij 65 (9,9\%) patiënten werd geen biopsie verricht, bij 43 (6,5\%) patiënten werden beide verricht. Pathologische beoordeling toonde een maligne tumor aan bij $406(61,6 \%)$ patiënten, een benigne laesie bij $83(12,6 \%)$ patiënten en een inconclusieve beoordeling bij $170(25,8 \%)$ patiënten. Patiënten die enkel een periablatief biopt kregen werden significant vaker behandeld voor een benigne laesie $(p=0,0324)$. In de preablatieve groep werd bovendien va- 
ker een diagnose gesteld $(89,9 \%)$ in vergelijking met de periablatieve groep $(83,7 \%)(p=0,1198)$.

\section{Conclusie}

Een periablatieve nierbiopsie toonde een hoger percentage behandeling van benigne tumoren. Deze resultaten wijzen erop dat een preablatief biopt de voorkeur heeft, om onbedoelde overbehandeling te voorkomen.

\section{Patient reported outcome measures (PROMs) en patient reported experience measures (PREMs) voor niersteenpatiënten}

J.B.M. Jacobs, S. Weltings, R.C.M. Pelger en B.M.A. Schout Alrijne Ziekenhuis, Leiderdorp

\section{Introductie}

Het meten van kwaliteit van zorg met PROMs (patient reported outcome measures) en PREMs (patient reported experience measures) wordt steeds belangrijker. Voor de behandeling van nierstenen zijn nog geen studies met PROMs beschreven. Met deze studie evalueerden we de uitkomsten van ESWL- en URS-behandelingen met PROMs en PREMs.

\section{Materiaal en methoden}

Er werd een longitudinaal vragenlijst onderzoek bij urolithiasispatiënten die waren behandeld met ESWL of URS. Patienten vulden één vragenlijst in direct na behandeling (T0: respons $69,8 \% ; n=51$ ) en één vragenlijst tien dagen na behandeling (T1: respons $56 \% ; n=42$ ).

\section{Resultaten}

Het hebben van nierstenen heeft op baseline bij 29,2\% van de patiënten in de ESWL-groep invloed op het uitvoeren van dagelijkse activiteiten; na behandeling is dat $54,2 \%$. In de URS-groep is dit respectievelijk $61,1 \%$ en dit blijft gelijk na behandeling. Pijn en ongemak worden op baseline door $58,3 \%$ van de ESWL-patiënten ervaren en door $88,9 \%$ van de URS-patiënten. $\mathrm{Na}$ behandeling is dit respectievelijk $58,3 \%$ en $66,7 \%$. In figuur 7.1 staan de resultaten voor hematurie en een branderig gevoel bij mictie beschreven. In de twee weken na behandeling gebruikt $45,8 \%$ van de ESWLpatiënten pijnstillers en 70,6\% van de URS-patiënten. ESWLpatiënten missen gemiddeld 1,26 werkdagen; URS-patiënten 5,61 werkdagen $(p=0,025)$. Qua PREMs (tevredenheid van patiënten over hun behandeling) scoorden beide groepen mediaan 4 (schaal $1-5 ; 4=$ tevreden).

\section{Conclusie}

Uit dit onderzoek is gebleken dat de behandeling van urolithiasis grote invloed heeft op het leven van de patiënt, dat patiënten die behandeld worden met URS meer werkdagen missen er dat er geen verschil is in patiënttevredenheid. Met dit onderzoek is de start gemaakt voor PROMs en PREMs bij urolithiasispatiënten in Nederland en dit kan invloed hebben op de keuzes die gemaakt worden in de spreekkamer.

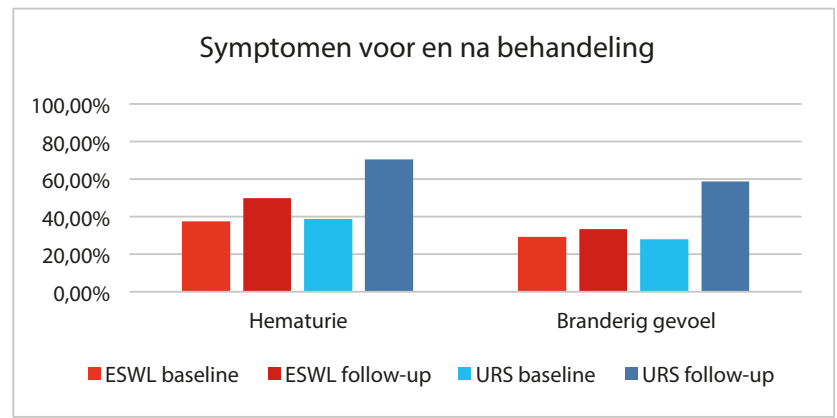

Figuur 7.1 Zelfrapportage van optreden van de symptomen voor en na behandeling

\section{De toevoegde waarde van triple sensor urethra- le katheter bij het aantonen van urethrale insta- biliteit tijdens de vullingsfase van urodynamisch onderzoek}

\author{
E. Bovelander, M. Kummeling, J. van Uhm, G. van Koeveringe, \\ H. Elzevier en P. Groenendijk \\ Haaglanden Medisch Centrum (HMC), Den Haag
}

\section{Introductie}

Urodynamisch onderzoek wordt regelmatig gebruikt bij de analyse van patiënten met lower urinary tract symptoms (LUTS). Indien continue urethrale drukmeting wordt toegepast, kan tijdens de vullingsfase urethrale drukvariatie worden opgemerkt. Hoewel dit fenomeen in meerdere studies wordt beschreven, is er nog altijd geen eenduidige definitie van urethrale instabiliteit (URI), is er geen consensus omtrent meettechnieken en blijft de klinische relevantie controversieel. Het doel van deze studie was om de continue urethrale drukmetingen tussen de standaard microtipkatheter met een enkele urethrale druksensor te vergelijken met die van een triple sensor urethrale katheter bij het aantonen van URI.

\section{Materiaal en methoden}

Deze prospectieve observatie studie is uitgevoerd tussen mei 2016 en juli 2018. Alle volwassen vrouwen die in staat waren tot het geven van toestemming werd gevraagd deel te nemen aan de studie. Alle patiënten ondergingen twee series onderzoeken met vullings- en mictiefasen, waarvan één serie met de standaard microtip sensor katheter en de andere serie met de triple sensor katheter. UI werd gedefinieerd als een drukverval van meer dan $40 \mathrm{cmH}_{2} \mathrm{O}$. Alle onderzoeken 
werden gedaan door dezelfde gespecialiseerde verpleegkundige.

\section{Resultaten}

Er werden 75 patiënten geïncludeerd in de studie. De gemiddelde leeftijd bedroeg 54 jaar. De prevalentie van urethrale instabiliteit was 33,3\% (25 van de 75 patiënten). De triple sensor katheter detecteerde een significant hoger aantal URI (22 van de 25) in vergelijking met de standaard microtip katheter (11 van de $25 ; p=0,013)$. Er was geen significant verschil tussen de gemeten volumes gedurende de vullingsfasen tussen de patiënten met en zonder URI (tabel 8.1).

\section{Conclusie}

URI is een veel voorkomend probleem, dat wordt geobserveerd bij een derde van patiënten in deze studie. Hoewel de klinische relevantie vooralsnog niet duidelijk is, onderbouwt deze studie de noodzaak van verder onderzoek. Uit onze data kan geconcludeerd worden dat het gebruik van een triple sensor urethrale katheter tijdens vullingsfasen toegevoegde waarde heeft voor het detecteren van urethrale instabiliteit.

Tabel 8.1 Urethrale instabiliteit bij de dual microtip $v s$. de triple sensor katheter

\begin{tabular}{lllll}
\hline \multicolumn{5}{l}{ triple sensor } \\
\hline dual microtip & geen URI & 50 & 14 & 64 \\
\cline { 2 - 5 } \begin{tabular}{l} 
(één sensor) \\
\cline { 2 - 5 }
\end{tabular} & URI & 3 & 8 & 11 \\
\cline { 2 - 5 } & totaal & 53 & 22 & 75 \\
\hline
\end{tabular}

URI urethrale instabiliteit

\section{Prospectieve analyse van het effect van een beta-3-adrenoreceptoragonist op urethrale instabi- liteit bij vrouwen met $O A B$ tijdens de vullingsfase van urodynamisch onderzoek}

\author{
J. Egberts, M. Kummeling, H. Elzevier en P. Groenendijk \\ Haaglanden Medisch Centrum, Den Haag
}

\section{Introductie}

Patiënten met overactieve blaasklachten (OAB) ervaren een toegenomen plasfrequentie en/of een hevige aandrang om te plassen. Bij de analyse van deze klachten wordt regelmatig urodynamisch onderzoek (UDO) verricht. In de vullingsfase van het UDO kunnen urethrale drukschommelingen worden waargenomen. De klinische relevantie hiervan is tot heden controversieel. Een recente review concludeerde dat ondanks de matige methodologische kwaliteit van de beschikbare literatuur, urethra-instabiliteit (UI) mogelijk een eigen entiteit is binnen OAB. Sinds enkele jaren is er een beta-3-adrenoceptoragonist (mirabegron) beschikbaar voor de behandeling van OAB. Theoretisch zou mirabegron een stabiliserende werking kunnen hebben op urethra-instabiliteit. In deze studie is gemeten wat het effect is van mirabegron op de urethrale druk tijdens vullingscystometrie.

\section{Materiaal en methoden}

In deze prospectieve studie werden 51 vrouwelijke patiënten met $\mathrm{OAB}$ geïncludeerd. Evaluatie van patiënten bestond uit het invullen van een mictielijst en twee gevalideerde vragenlijsten (UDI-6 en IIQ), als ook een urodynamisch onderzoek (UDO). Vervolgens werd gestart met mirabegron 50 mg eenmaal daags. Na zes weken werden de vragenlijsten opnieuw ingevuld en werd het urodynamisch onderzoek herhaald. UI werd gedefinieerd als een drukverval van $>40$ $\mathrm{cmH}_{2} \mathrm{O}$.

\section{Resultaten}

42 patiënten ondergingen twee UDO's en 49 patiënten ondergingen er één. Tijdens het eerste UDO trad bij 31\% van de patiënten UI op tijdens het tweede UDO bij 19\% van de patiënten. Dit verschil was niet significant. Uit de vragenlijsten bleek dat behandeling met mirabegron leidde tot een significante afname van klachten op het vlak van actieve ontspanning (IIQ: $p=0,005$; UDI-6: $p=0,031$ ), kleine hoeveelheden urineverlies (UDI-6: $p=0,011$ ) en emotionele gezondheid (IIQ: $p=0,011$ ). De parameters die tijdens het UDO waren gemeten, verbeterden significant bij zowel first desire, normal desire als strong desire (resp. $p=0,019, p=$ 0,015 en $p=0,020$ ).

\section{Conclusie}

Mirabegron geeft een significante subjectieve verbetering van OAB-klachten en een significante verbetering van aandranggevoel bij UDO. Er werd geen significante invloed aangetoond op UI.

\section{Luxatie van ballon-nefrostomiekatheters: de invloed van het type vloeistof als ballonvulling}

\author{
M.J.H. Voskamp, M.S. Vallinga en S. Roemeling \\ Universitair Medisch Centrum Groningen, Groningen
}

\section{Introductie}

In onze kliniek wordt als nefrostomiekatheter frequent een open end ballonkatheter gebruikt. Het is bekend dat de ballon van een katheter langzaam leegloopt. Derhalve wordt de vulling van de ballon periodiek gecontroleerd door een verpleegkundige om luxatie te voorkomen. Aangezien deze handeling in onervaren handen ook het risico op luxatie met zich meebrengt, hebben we onderzocht hoe snel de ballon- 


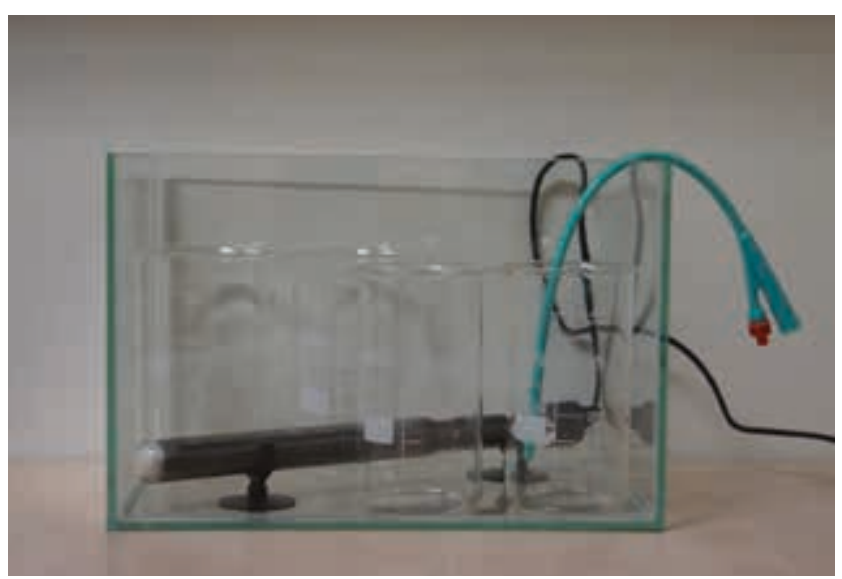

Figuur 10.1 Proefopstelling met de bekerglazen, temperatuurregulator en katheter

nen daadwerkelijk leeglopen en of een alternatieve vulling met glycerine $10 \%$ een zinvol alternatief zou kunnen zijn, zodanig dat periodieke balloncontrole niet meer nodig is.

\section{Materiaal en methoden}

Vijftien Ch16 siliconen open end katheters werden verdeeld over drie groepen van vijf katheters. De ballonnen van groep 1 werden gevuld met steriel water, bij groep 2 met $10 \%$ glycerine in steriel water en bij groep 3 met water, en wekelijks geleegd en gevuld zoals in de huidige praktijk. Alle ballonnen werden gevuld met de door de fabrikant aangegeven hoeveelheid $(5 \mathrm{ml})$. De katheters werden in een afgesloten systeem gehangen met een vloeistof die qua condities gelijk is aan urine ( $\mathrm{pH}$, zouten, temperatuur). Wekelijks werd de diameter van de ballon opgemeten. Zie figuur 10.1 .

\section{Resultaten}

De vulling van de ballonnen in groep 3 (wekelijks controle) bleef gelijk. De ballonnen die gevuld waren met water (groep 1) namen in diameter per week gemiddeld 2,1\% (SD $\pm 0,8)$ af tot een gemiddeld volume van $2,5 \mathrm{ml}(\mathrm{SD} \pm 0,1)$ na 10 weken, terwijl de ballonnen die gevuld waren met glycerine (groep 2) met 1,1\% (SD $\pm 0,7)$ in diameter per week toenamen tot een gemiddeld volume van 7,1 $\mathrm{ml}(\mathrm{SD} \pm 0,2)$. Alle ballonnen konden na 10 weken geleegd worden.

\section{Conclusie}

In tegenstelling tot het gebruik van water als vulling van de katheterballon, loopt de ballon die gevuld is met glycine $10 \%$ over een periode van 10 weken niet leeg. Dit maakt dat periodieke balloncontrole niet nodig is, waarmee een belangrijk risicomoment voor katheterluxatie vermeden wordt. Bovendien kan dit een reductie geven van kosten en inspanningen van zorgverleners.

\section{Tweedelijns diagnose van disfunctie van de lage urinewegen bij mannen $>45$ jaar, verwezen met klachten; objectieve stadiëring en gradering}

\author{
P.F.W.M. Rosier \\ Universitair Medisch Centrum Utrecht, Utrecht
}

\section{Introductie}

Mannen boven de 45 jaar met klachten of verschijnselen van disfunctie van de lage urinewegen worden door de huisarts begeleid met aandacht voor levensstijl en de invloed van de klachten op het welbevinden, en eventueel met medicatie. Als symptomen desondanks persisteren, volgt verwijzing voor nadere diagnostiek en behandeling. Van de tweedelijnszorg wordt verwacht dat objectieve vaststelling van pathofysiologie de aandacht voor belevingsaspecten zal aanvullen. Symptomen associëren met de mate van hinder en zorgen. Uroflowmetrie geeft de resultante van detrusorcontractiekracht en blaasuitstroomobstructie (BOO), en een groter prostaatvolume is geassocieerd met toenemende kans op BOO. Deze gegevens kunnen in de tweede lijn leiden tot betere (dan de HA) schatting van de kans op specifieke pathofysiologie. Exactere gradering van de disfunctie is gestandaardiseerd (door de ICS) sinds 1997.

\section{Materiaal en methoden}

Wij onderzochten in een cohort van 2459 verwezen mannen (55 \pm 24 jaar; 67\% medicatieresistent; IPSS: 16,6; QuoL $3,9)$ hoe objectieve stadiëring van de disfunctie na verwijzing het behandeladvies beïnvloedde. We rapporteren resultaten van standaard uroflowmetrie en cystometrie met drukflowstudies.

\section{Resultaten}

$28, \%$ van alle mannen had $\mathrm{BOO}(>2)$ en $3 \%$ van alle mannen 'fors' (OBS > 4). 4,7\% van de mannen met BOO had contractiekracht onder de norm. Geen of minimale BOO met verminderde contractiekracht werd aangetoond bij

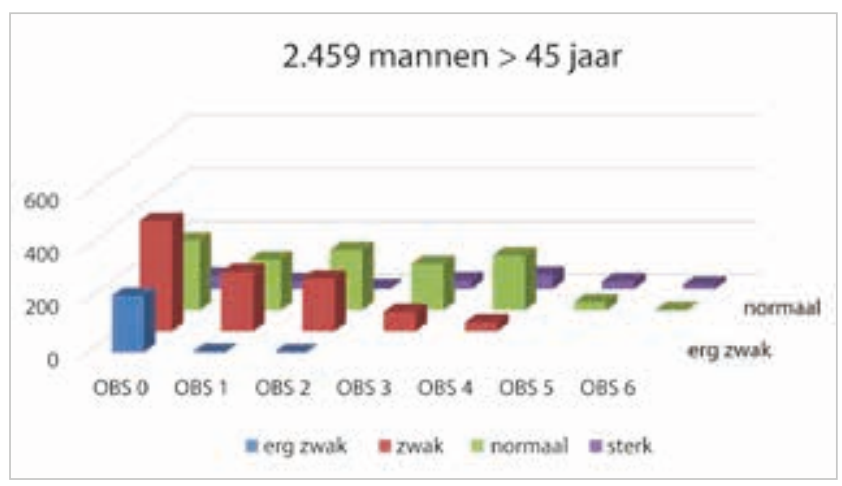

Figuur 11.1 $Y$ as aantal. $X$-as BOO van 0-6. Z-as detrusorkracht: vooraan zwak, achter normaal-sterk 
$37,7 \%$ van de mannen en $34 \%$ had normale contractiekracht zonder BOO. $43 \%$ van de mannen had detrusoroveractiviteit plus $4 \%$ alleen 'terminaal'. Uroflowmetrie $>14 \mathrm{~mL} / \mathrm{s}$ voorspelde $85,6 \%$ géén $\mathrm{BOO}$ en $56,2 \%$ normale contractiekracht. Een resultaat $<10 \mathrm{~mL} / \mathrm{s}$ voorspelde $38 \%$ zwakke detrusorcontractie en $88 \%$ BOO.

\section{Conclusie}

Objectieve disfunctiestadiëring van verwezen mannen leidde tot geïndividualiseerd en gefundeerd starten of wijzigen $(27,2 \%)$ of stoppen $(8,7 \%)$ of continuering $(18,5 \%)$ van de medicamenteuze behandeling. (Veel) minder dan 30\% werd chirurgische desobstructie geadviseerd, en gedaan $(19,6 \%)$. Zie figuur 11.1.

\section{Ontwikkeling en externe validatie van een multivariabel multicenter model voor de voorspelling van positieve lymfeklieren bij 4.459 Nederlandse mannen die een RARP voor prostaat- kanker ondergingen}

E.R.P. Collette, S. Klaver, P.C. Weijerman, M. Gan, C.J. Wijburg en A.N. Vis

Rijnstate, Arnhem

\section{Introductie}

In Nederland worden buitenlandse voorspellende modellen gebruikt voor preoperatieve inschatting van kans op positieve lymfeklieren bij pelviene lymfeklierdissectie bij robotgeassisteerde radicale prostatectomie (RARP). Deze nomogrammen hoeven niet op te gaan voor Nederlandse mannen. Deze studie heeft tot doel een Nederlands prognostisch model te ontwikkelen en extern te valideren.

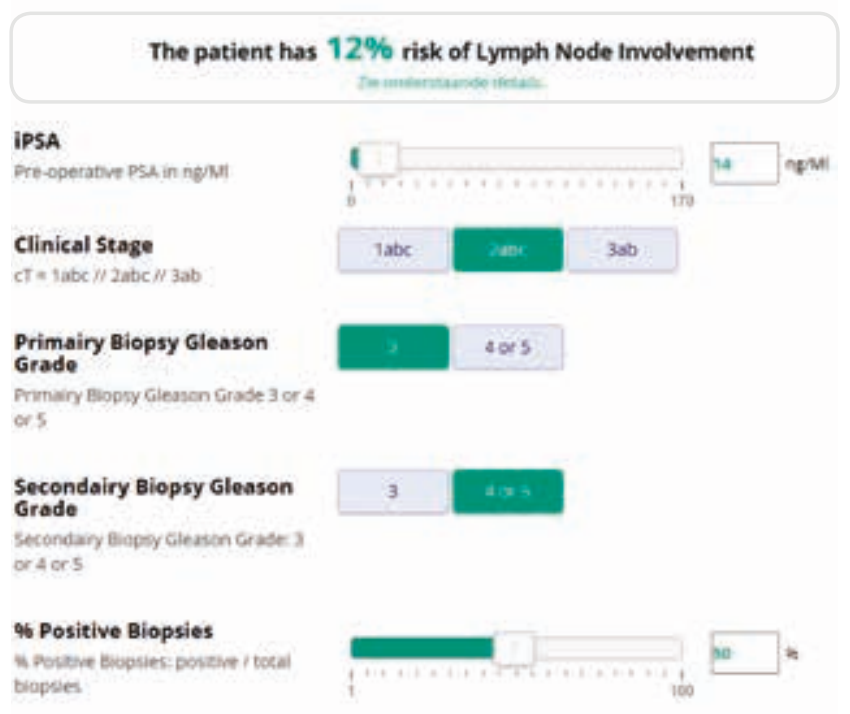

Figuur 12.1 Het risico op lymfekliermetastasen

\section{Materiaal en methode}

Gegevens werden geëxtraheerd uit de lokale RARP-databases van de drie prostaatkankernetwerken (PKNW). In totaal ondergingen 4.459 mannen een RARP tussen 2009 en 2018. Bij 1.413 (32\%) mannen werd ook een pelviene lymfeklierdissectie (PLKD) uitgevoerd. Het voorspellende model is gebaseerd op 937 patiënten uit twee PKNW in Nederland. Multivariabele logistische regressie werd uitgevoerd om de voorspellende waarde van de klinische parameters gerelateerd aan positieve lymfeklierstatus te beoordelen. Zie figuur 12.1 voor de parameters. Externe validatie is gebaseerd op data van een derde regionaal PKNW met 476 patiënten.

\section{Resultaten}

Bij 230 (16\%) patiënten werden positieve lymfeklieren gevonden. iPSA is geen significante voorspeller $(p=0,17$; HR $=1,01)$. Klinisch tumorstadium cT2abc en cT3ab zijn significante voorspellers ( $p<0,001$; HR $=2,00$ en HR 6,94), evenals de Gleason-grade 4 en $5(p=0,014 ; \mathrm{HR}=1,64)$ bij de primaire biopsie. Het percentage positieve biopten is ook een significante voorspeller $(p<0,001 ; \mathrm{HR}=1,01)$. De area under the ROC curve is 0,75 . Bij externe validatie is er een discriminatie met een $\mathrm{C}$-index $0,62(95 \%-\mathrm{BI}=0,55-0,69)$ en een kalibratie met een regressiecoëfficiënt van 0,35 en een intercept van 0,07 , met een optimum rond de $10-11 \%$ voorspelde kans.

\section{Conclusie}

Wij presenteren een model voor de preoperatieve voorspelling van positieve lymfeklieren bij PLKD bij prostaatcarcinoom. Er is een goede diagnostische waarde. Externe validatie toonde een redelijke discriminatie en een goede gemiddelde voorspelde uitkomst bij kalibratie met een optimum rond de huidige NVU drempelwaarde voor een lymfeklierdissectie. Dit Nederlandse model kan worden gebruikt om op basis van deze preoperatieve variabelen een uitspraak te doen over de kans op regionale lymfekliermetastasen op individuele basis.

\section{De waarde van PSMA PET/CT bij patiënten met een biochemisch recidief na radicale prosta- tectomie}

H.B. Luiting, P.J. van Leeuwen, S. Remmers, M.B. Busstra en M.J. Roobol-Bouts

Erasmus MC, Rotterdam

\section{Introductie}

De EAU-richtlijn van 2019 adviseert een PSMA-scan te maken bij een biochemisch recidief (BCR) bij PSA $>0,2 \mathrm{ng} /$ $\mathrm{ml}$ na een radicale prostatectomie (RP) onder voorbehoud 

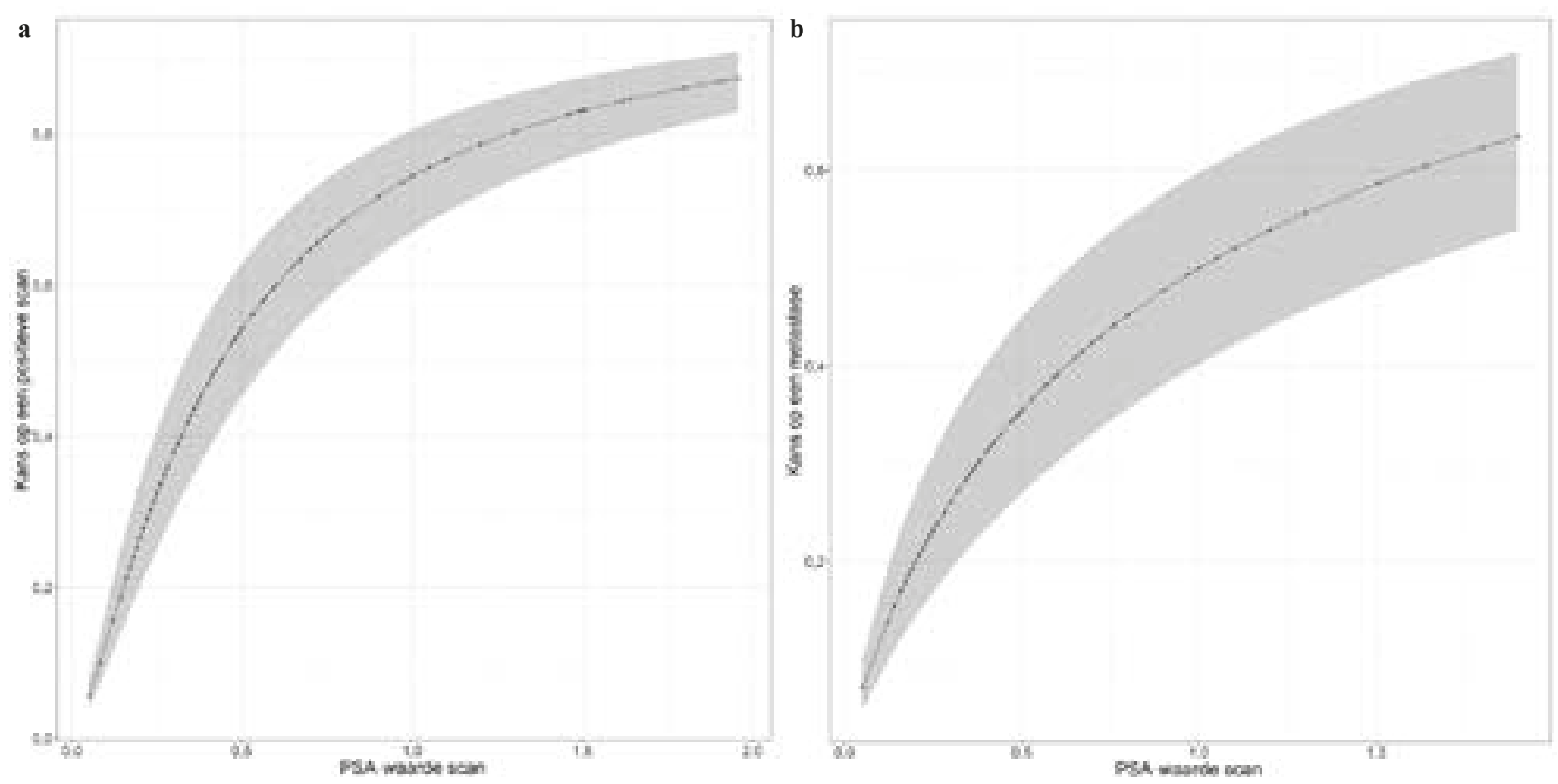

Figuur 13.1 a De kans op een positieve PSMA-scan bij verschillende PSA-waarden. b De kans op het detecteren van metastasen (lokaal of op afstand) bij patiënten die in aanmerking komen voor salvage radiotherapie op het prostaatbed.

dat het resultaat de besluitvorming omtrent verdere behandeling beïnvloedt. Voor patiënten met een BCR na RP is salvage radiotherapie op de prostaatfossa (sRT) een in opzet curatieve behandeling met hogere effectiviteit bij lagere PSA-waarden. Detectie van metastasen voor sRT leidt echter tot een beleidswijziging. We onderzochten de kans op een positieve PSMA-scan en de kans op het detecteren van metastasen bij een PSA $<2 \mathrm{ng} / \mathrm{ml}$.

\section{Materiaal en methoden}

Inclusiecriteria waren: (a) het ondergaan van een ${ }^{68} \mathrm{Ga}$-PSMA-scan vanwege een BCR (gedefinieerd als PSA $>0,01$ $\mathrm{ng} / \mathrm{ml}$ ) na een RP, (b) geen behandeling tussen de RP en de PSMA-scan en (c) een PSA $<2 \mathrm{ng} / \mathrm{ml}$ ten tijde van de PSMAscan. Klinische en pathologische variabelen en de scanuitslag werden retrospectief verzameld. Door middel van een multivariate logistische regressie werd onderzocht of (a) PSA ten tijde van de scan, (b) het pT-stadium en (c) de RP-grade de uitkomst van de scan kon voorspellen.

\section{Resultaten}

242 patiënten werden geïncludeerd in twee centra. Het mediane PSA ten tijde van de scan was 0,40 (interkwartielafstand $0,27-0,57) \mathrm{ng} / \mathrm{ml}$. De PSMA-scan was positief bij 116 (48\%) patiënten. Alleen het PSA ten tijde van de scan was gecorreleerd aan de kans op een positieve scan (figuur 13.1a). Door de detectie van metastasen werd bij 59 (31\%) van de 190 patiënten (pN1-patiënten geëxcludeerd) afgezien van sRT. De kans op het detecteren van metastasen met het bijbehorende PSA in deze groep patiënten is weergegeven in figuur $13.1 \mathrm{~b}$.

\section{Conclusie}

De kans op een positieve PSMA-scan neemt toe met een stijgend PSA. Ook de kans op het detecteren van metastasen en daarmee een beleidswijziging bij patiënten die in aanmerking komen voor sRT neemt toe met een stijgend PSA, $20 \%$ bij een PSA van $0,2 \mathrm{ng} / \mathrm{ml}$ en $31 \%$ bij een PSA van 0,4 $\mathrm{ng} / \mathrm{ml}$. Deze resultaten kunnen helpen om de balans tussen een betere kans op genezing door vroege sRT en het voorkomen van onnodige sRT door de detectie van metastasen te kunnen afwegen.

\section{De waarde van de PSMA-scan bij patiënten met een biochemisch recidief na radicale prosta- tectomie gevolgd door salvage radiotherapie}

\author{
H.B. Luiting, P.J. van Leeuwen,S. Remmers, M.B. Busstra en \\ M.J. Roobol-Bouts \\ Erasmus MC, Rotterdam
}

\section{Introductie}

Patiënten met een biochemisch recidief (BCR) na radicale prostatectomie (RP) en salvage radiotherapie op de prostaatfossa (sRT) kunnen in aanmerkingen komen voor PSMAPET/CT-gestuurde behandelingen. Te vroeg scannen leidt tot negatieve scans en dus geen gerichte behandeling, te laat 


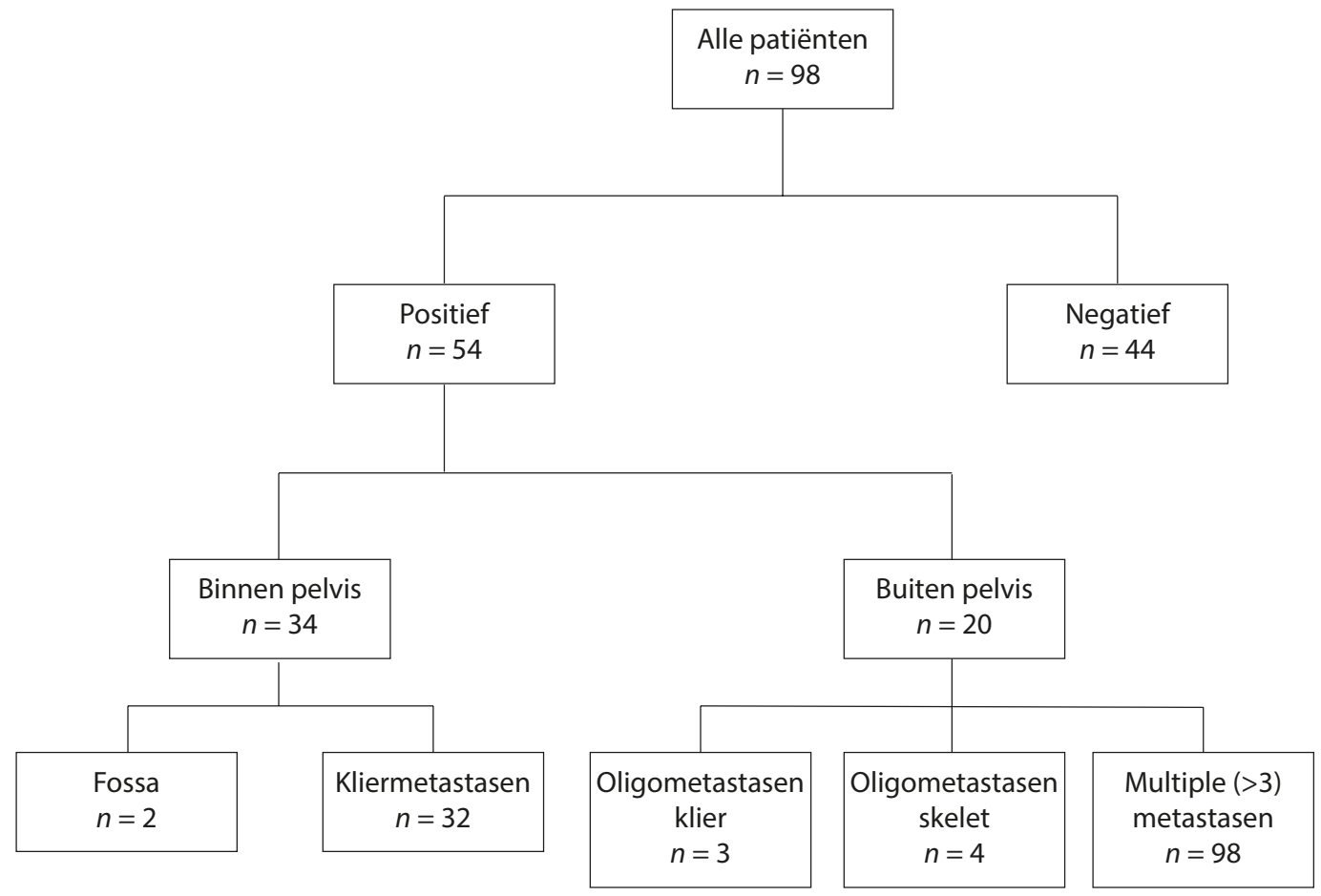

Figuur 14.1 De locatie van het prostaatrecidief gedetecteerd door ${ }^{68} \mathrm{Ga}-\mathrm{PSMA}$ PET/CT, waarbij de definitie van $\leq 3$ metastasen als oligometastatische ziekte is gehanteerd

scannen maakt een eventuele behandeling van een locoregionaal recidief of oligometase niet meer mogelijk. We onderzochten de kans op een positieve PSMA-scan en de locatie van het recidief bij patiënten met een PSA $<2 \mathrm{ng} / \mathrm{ml}$ na een RP gevolgd door sRT.

\section{Materiaal en methoden}

Inclusiecriteria waren: (a) het ondergaan van een PSMAscan vanwege een klinisch vastgesteld BCR na RP en sRT, (b) geen behandelingen tussen sRT en de PSMA-scan en (c) een PSA $<2 \mathrm{ng} / \mathrm{ml}$ ten tijde van de PSMA-scan. Klinische en pathologische gegevens en de scanuitslag werden verzameld. Met een multivariate logische regressie berekenden we de voorspellende waarde van het PSA ten tijde van de scan, het pT-stadium en de RP Gleason-score voor de uitkomst van de PSMA-scan.

\section{Resultaten}

98 patiënten werden retrospectief geïncludeerd. Het mediane PSA ten tijde van de scan was 0,61 (interkwartielafstand 0,401,00) ng/ml. Bij 54 (55\%) patiënten detecteerde de PSMA-scan een tumorrecidief. Alleen de PSA-waarde ten tijde van de scan was een voorspeller voor de uitkomst van de scan met de mediane kans op een positieve scan van 35\% bij patiënten met een PSA van $0,17-0,47 \mathrm{ng} / \mathrm{ml}, 56 \%$ bij een PSA van $0,48-$ $0,85 \mathrm{ng} / \mathrm{ml}$ en $75 \%$ bij een PSA van $0,86-1,86 \mathrm{ng} / \mathrm{ml}$. De locatie van het tumorrecidief is weergegeven in figuur 14.1.

\section{Conclusie}

In onze studie is PSA de enige voorspeller voor de uitkomst van de PSMA-scan bij patiënten met een BCR na RP en sRT. Indien een tumorrecidief werd gedetecteerd, was dit in de meeste gevallen een locoregionaal recidief ( 34 van de 54 patiënten). Op het moment van scannen moet er een balans zijn tussen de kans op een positieve scan en het verstrijken van de periode waarin gerichte behandeling nog mogelijk is. Deze data kunnen helpen inzicht te krijgen in de verwachte uitkomst van de scan. De waarde van PSMA-gerichte behandelingen dient verder te worden onderzocht.

\section{Detectie van klinisch significant prostaat- kanker in biopsienaïeve mannen: multipara- metrische MRI- en contrastversterkte echografie- geleide biopsie in vergelijking met de standaard systematische biopsie}

C.K. Mannaerts, M.R.W. Engelbrecht, A.W. Postema, R.A.A. van Kollenburg, R.R. Wildeboer, M. Mischi, Th.M. De Reijke en H. Wijkstra

Amsterdam UMC, Universiteit van Amsterdam, Amsterdam

\section{Introductie}

Kwantificatie van contrastversterkte echografie (CEUS) heeft veelbelovende resultaten getoond voor de detectie van 
Tabel 15.1 Vergelijking van de detectie van klinisch-significant en insignificant prostaatkanker voor de drie verschillende biopsiestrategieën: TRUSGB, MRIGB en CEUSGB

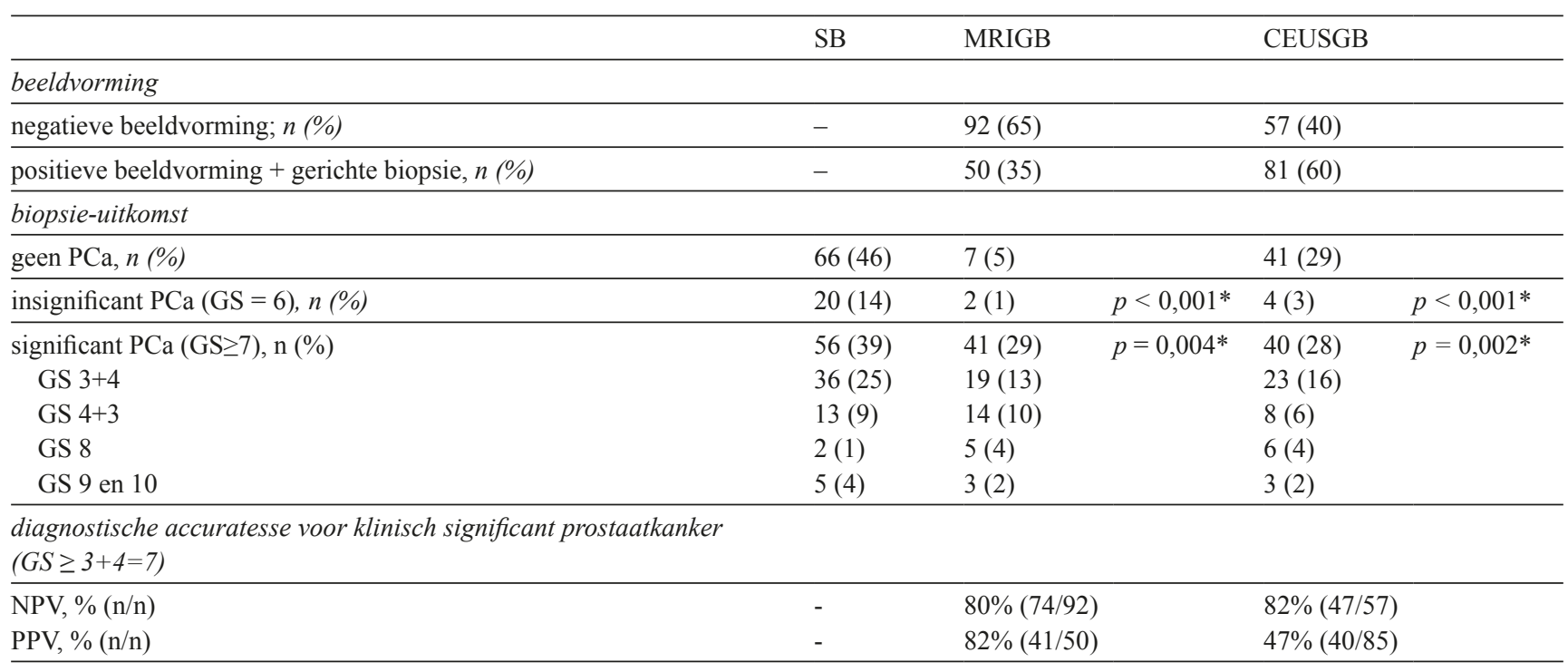

* Significant verschil in detectie tussen de SB en de imaging-GB (MRIGB of CEUSGB) middels de McNemarTest voor gepaarde data.

prostaatkanker $(\mathrm{PCa})$, maar grote klinische studies ontbreken. Ondertussen heeft de multiparametrische MRI (mpMRI) geleide prostaatbiopsie (GB) zich ontwikkeld tot een alternatief voor de systematische transrectale echogeleide systematische biopsie (SB). Het achterwege laten van SB blijft echter controversieel. In deze prospectieve studie vergeleken we de detectie van klinisch significante PCa van MRGB en CEUSGB met standaard SB bij biopsienaïeve mannen.

\section{Materiaal en methoden}

150 biopsienaïeve mannen zijn geïncludeerd na informed consent. De prebiopsie mpMRI (T2-, diffusie-, en dynamische contrastversterkte MRI) werd beoordeeld door één radioloog middels PI-RADSv2. De CEUS (4 contrastopnames en kwantificatie van de opnamen met parametrische maps) werd beoordeeld door één CEUS-expert middels een Likert-schaal van $1-5$. Alle mannen ondergingen een SB (12 biopten) door een operateur die was geblindeerd voor de beeldvorming. Een tweede operateur voerde aansluitend de CEUSGB (Likert $\geq 3$ ) en MRI TRUS-fusie-GB (PI-RADS $\geq 3$ ) uit. Detectie van klinisch significante PCa (Gleason-score $(\mathrm{GS}) \geq 3+4)$ en insignificant prostaatkanker (GS = $3+3)$ werd vergeleken tussen de drie biopsiestrategieën. Negatieve (NPV) en positief voorspellende waarde (PPV) van mpMRI en CEUS voor klinisch-significant prostaatkanker werd bepaald.

\section{Resultaten}

142 mannen waren beschikbaar voor analyse. In totaal werd $\mathrm{GS} \geq 3+4-\mathrm{PCa}$ bij 62 mannen (44\%) gevonden en GS = 3+3-PCa bij 18 mannen (13\%). SB detecteerde significant meer GS $\geq 3+4$ - en GS $=3+3-\mathrm{PCa}$ dan MRGB of CEUSGB (alle $p<0,05$ ). De NPV van MRI en CEUS voor GS $\geq 3+4$ PCa was vergelijkbaar ( $80 \%$ versus $82 \%$ ), terwijl de PPV van MRI hoger was dan CEUS (82\% versus 47\%) (tabel 15.1).

\section{Conclusies}

SB detecteerde in onze studie meer klinisch significante en insignificante prostaatkanker dan MRIGB en CEUSGB. SB kan niet achterwege gelaten worden in biopsienaïeve mannen op basis van negatieve beeldvorming alleen.

\section{Chemoradiatie ter behandeling van locoregionaal gevorderd peniscarcinoom}

S.R. Ottenhof, B. Doodeman, G.L. Vrijenhoek, R.S. Djajadiningrat, S. Horenblas en F.J. Pos

Antoni van Leeuwenhoek, Amsterdam

\section{Introductie}

Behandeling van locoregionaal gevorderd peniscarcinoom is uitdagend, gezien de vele bijwerkingen van die behandeling. De rol van chemoradiatie (CTRT) is nauwelijks beschreven, terwijl deze behandeling bij andere plaveiselcelcarcinomen van grote therapeutische waarde is. Wij evalueerden de effectiviteit en toxiciteit van CTRT voor locoregionaal gevorderd peniscarcinoom.

\section{Materiaal en methoden}

Patiënten werden geïncludeerd volgens de volgende criteria: zeer grote of inoperabele primaire tumor (T3-T4), grote 
klier $(>3 \mathrm{~cm})$ in de lies $(\mathrm{cN} 2)$, verdenking op extranodale groei of bekkenkliermetastasen (cN3), en zonder tekenen van afstandsmetastasen. Radiatie bestond uit electieve radiotherapie van penis en/of liezen en/of bekkenklieren (33 x 1,5 Gy) met een surdosage op PET-positieve laesies (33 x $1,8 \mathrm{~Gy})$. Chemotherapie bestond uit mitomycine $\mathrm{C}(10 \mathrm{mg} /$ $\mathrm{m}^{2}$ i.v.) op dag 1 en capecitabine ( $2 \mathrm{dd} 825 \mathrm{mg} / \mathrm{m}^{2}$, tabletten) op bestralingsdagen. We keken naar progressievrije overleving (PVO), totale overleving (TO), en ernstige complicaties (EC). Complicaties werden gescoord volgens de National Cancer Institute Common Terminology Criteria for Adverse Events (CTCAE) versie 4.0, waarbij graad 3 en 4 als ernstig werden aangemerkt.

\section{Resultaten}

34 patiënten werden geïncludeerd. Op een na konden zij allen de behandeling voltooien. Niemand stierf aan een andere oorzaak dan peniskanker. Met een mediane volgtermijn van 25,6 maanden is de PVO 26\% na één jaar en 21\% na twee jaar. Mediane progressievrije overleving was 5,5 maanden. TO was $50 \%$ na één jaar en $26 \%$ na twee jaar. Deze resultaten zijn grofweg hetzelfde als eerdere studieresultaten uit ons centrum naar behandeling met neoadjuvante chemotherapie, chirurgie en adjuvante radiotherapie. Toxiciteit was relatief laag. Tijdens de behandeling kregen 14 patiënten (41\%) een ernstige complicatie (veelal dermatitis en/of lymfoedeem). Tijdens het vervolg kregen 11 patiënten een ernstige complicatie.

\section{Conclusie}

Chemoradiatie is een goed te verdragen behandelalternatief voor locoregionaal gevorderd peniscarcinoom. De overlevingscijfers zijn net zo teleurstellend als bij andere behandelingen; een voordeel is het relatief lage voorkomen van complicaties.

\section{Een retrospectieve evaluatie van de huidige diagnostiek bij vrouwen met ongecompliceerde recidiverende urineweginfecties}

\author{
J.J. Pat, M.G. Steffens en M.H. Blanker \\ Isala, Zwolle
}

\section{Introductie}

Urineweginfecties (UWI's) zijn een van de meest voorkomende bacteriële infecties. Bij een deel van de patiënten is een UWI recidiverend. De NHG-Standaard UWI adviseert verwijzing als, ondanks de profylaxe. de UWI recidiveren. In ons ziekenhuis worden wekelijks gemiddeld 2-3 nieuwe patiënten gezien die zijn doorverwezen vanwege urineweginfecties. Zij krijgen standaard en aanvullende diagnostiek aangeboden waarvan verwacht wordt dat de opbrengst laag is. Het in kaart brengen van het diagnostisch traject en het onderzoeken van voorspellers voor het uitvoeren van aanvullende diagnostiek is daarom wenselijk.

\section{Materiaal en methoden}

Deze studie is een retrospectieve analyse die is gebaseerd op klinische data van patiënten die tussen 1 januari 2016 en 31 december 2017 zijn verwezen vanwege recidiverende urineweginfecties, zoals geregistreerd in het elektronisch patiëntendossier. De opbrengsten van de standaard en aanvullende diagnostiek zijn in kaart gebracht. De data zijn geanalyseerd om mogelijke voorspellers voor het wel of niet uitvoeren van aanvullende diagnostiek te identificeren middels logistische regressie.

\section{Resultaten}

Er werden 204 patiënten opgenomen in de analyse. De mictielijst toonde een inadequate intake bij 32 patiënten. Uroflowmetrie onthulde 57 afwijkingen en veranderde de therapie voor 41 patiënten. In totaal kregen 149 patiënten aanvullende diagnostiek, 104 cystoscopieën en 108 echografieën. Daarmee werden 13 afwijkingen gevonden, waarvan zes tot een afwijkende behandeling hebben geleid. Patienten met een normale echografie hadden ook een normale cystoscopie. Leeftijd en hematurie gingen gepaard met een hogere kans op aanvullende diagnostiek $(p<0,05)$.

\section{Conclusie}

Uroflowmetrie had de meeste opbrengst van alle diagnostiek en kan geschikt zijn als eerstelijns diagnosticum. De opbrengst van zowel cystoscopie als echografie was minimaal. Bij jonge vrouwen en patiënten met een normale echografie kan een cystoscopie mogelijk achterwege gelaten worden. In onze studie was de kans op krijgen van aanvullende diagnostiek hoger met een toename van de leeftijd en de aanwezigheid van hematurie.

\section{De (on)zin van een transurethrale resectie van de prostaat na acute urineretentie}

\author{
A. Lenting, A.V. van Lingen, J.H. Wolterbeek en L.A. 't Hoen \\ Franciscus Gasthuis, Rotterdam
}

\section{Introductie}

Lower urinary tract symptoms (LUTS) als gevolg van benigne prostaatobstructie komen veel voor en hebben invloed op de kwaliteit van leven. Er zijn verschillende indicaties voor prostaatchirurgie, waaronder acute urineretentie (AUR), recidiverende urineweginfecties en medicatieresistente klachten. In deze studie werd gekeken of een AUR preoperatief invloed heeft op het spontaan tot mictie komen na een transurethrale resectie van de prostaat (TURP). 


\section{Materiaal en methoden}

Het betreft een retrospectief cohortonderzoek, waarbij alle patiënten met een TURP die werd verricht in verband met LUTS of AUR tussen 2013 en 2018 werden geïncludeerd. De primaire uitkomstmaat was spontane postoperatieve mictie. De primaire determinant was preoperatieve retentie. Secundaire determinanten betroffen het preoperatieve retentievolume en het al dan niet peroperatief plaatsen van een suprapubische katheter.

\section{Resultaten}

In totaal ondergingen 850 patiënten een TURP in verband met LUTS (60\%) of AUR (40\%). De kans op niet-spontane mictie was 10 keer verhoogd indien er preoperatief sprake was van retentie. Bij iedere $500 \mathrm{ml}$ toename van het retentievolume preoperatief was de kans op niet-spontane mictie 1,4 keer groter (tabel 18.1). De kans op spontane mictie na TURP met voorafgaand een AUR van 2000-2500 ml dan wel groter dan $2500 \mathrm{ml}$ is $84 \%$ respectievelijk $76,5 \%$. Als tijdens de operatie een suprapubische katheter werd geplaatst, kwam de spontane mictie na gemiddeld 16,4 dagen op gang tegenover 5,1 dagen bij patiënten zonder suprapubische katheter.

\section{Conclusie}

Het doen van een TURP na een AUR is zinvol, met zelfs bij een AUR groter dan 2,5L nog een kans op spontane mictie van ruim $75 \%$. De kans op spontane mictie na TURP is echter wel 10 keer zo klein als zonder AUR preoperatief.

Tabel 18.1 Postoperatieve spontane mictie afhankelijk van het preoperatieve AUR-volume

\begin{tabular}{lll}
\hline AUR in $\mathrm{mL}$ & spontane mictie & niet-spontane mictie \\
\hline $0-499$ & $17(100 \%)$ & $0(0 \%)$ \\
\hline $500-999$ & $84(91,3 \%)$ & $8(8,7 \%)$ \\
\hline $1000-1499$ & $65(92,9 \%)$ & $5(7,1 \%)$ \\
\hline $1500-1999$ & $38(97,4 \%)$ & $1(2,6 \%)$ \\
\hline $2000-2499$ & $21(84,0 \%)$ & $4(16,0 \%)$ \\
\hline 2500 & $13(76,5 \%)$ & $4(23,5 \%)$ \\
\hline
\end{tabular}

19. Is de urethra van hypospadiepatiënten anders? Moleculaire analyse en karakterisering middels immunohistochemie

M.D.M. Viester, E. Gebben, G. Tsachouridis, L.M.O. de Kort en P. de Graaf

Regenerative Medicine Centre Utrecht, Groep Urologie

\section{Introductie}

Een op de 200-300 jongens in Nederland wordt geboren met een hypospadie. Correctie van hypospadie leidt frequent tot complicaties: onder andere dehiscentie, fistels en stricturen. Een mogelijke verklaring hiervoor is dat het weefsel van de hypospade urethra andere eigenschappen heeft dan de normale urethra. Het doel van deze studie is om door moleculaire karakterisering van urethraal weefsel van hypospadiepatiënten beter inzicht te krijgen in de eigenschappen van de hypospade urethra.

\section{Materiaal en methoden}

Restweefsel bij hypospadiecorrectie werd in paraffine ingebed en in coupes van $3 \mu \mathrm{m}$ gesneden. Hematoxyline-eosine (HE) kleuring en immunohistochemie werden uitgevoerd voor de androgeen receptor (AR), p63, von Willebrand-factor (vWF), elastine, keratine 7 (CK7) en Ki-67. Als controleweefsel werd de niet-hypospade urethra van restmateriaal na genderconformerende operatie gebruikt.

\section{Resultaten}

HE-kleuring liet een duidelijk verschil zien in het epitheel: bij hypospadiepatiënten bestond de urethrale plaat uit meerlaags epitheel, terwijl dit bij normale urethra's enkellaags epitheel is. p63 kwam in beide epithelia tot expressie. CK7 was afwezig in de hypospade urethra, terwijl CK7 bij niet-hypospade urethra wel tot expressie kwam. Vasculaire marker vWF was verlaagd bij hypospadie in vergelijking met de normale urethra, en er werden minder capillairen en minder of geen vasculaire ruimtes gezien. Tevens werd minder elastine gedetecteerd in hypospadieweefsel.

\section{Conclusie}

Er is een verschil tussen de hypospade en de niet-hypospade urethra. Het epitheel bij hypospadiepatiënten is meerlaags, in tegenstelling tot enkellaags in de normale urethra. Er is een verminderde aanwezigheid van capillairen, vasculaire ruimtes en minder elastine, mogelijk passend bij verminderde elasticiteit. De verminderde elasticiteit en verminderde doorbloeding van de subepitheliale laag zou het hoge complicatiepercentage na hypospadiecorrectie kunnen verklaren. 


\section{Papillary Urothelial Neoplasm of Low Malig- nant Potential (PUN-LMP): een valide histopatho- logische diagnose voor niet-spierinvasief blaascar- cinoom in 2019?}
A. Hentschel, B. van Rhijn, E. Compérat, M. Burger, K. Plass, O. Rodriguez, J-D. Subiela-Henríquez, V. Hernández, E. de la Peña, I. Alemany, D. Turturica, F. Pisano, F. Soria, O. Capoun, L. Bauerová, M. Pesl, M. Bruins, W. Runneboom, S. Herdegen, J. Breyer, A. Brisuda, A. Scavarda-Lamberti, J. Rubio-Briones, M. Seles, S. Mannweiler, J. Bosschieter, V. Kusuma, D. Ashabere, N. Huebner, J. Cotte, L. Mertens, D. Cohen, L. Lunelli,
O. Cussenot, S. El-Sheikh, D. Volanis, J-F. Coté, M. Rouprêt,
A. Haitel, S. Shariat, H. Mostafid, J. Nieuwenhuijzen,
R. Zigeuner, J. Dominguez-Escrig, J. Hacek, A. Zlotta, J. Bründl,
M. Evert, C. Hulsbergen-van de Kaa, A. van der Heijden,
B. Kiemeney, V. Soukup, L. Molinaro, P. Gontero, C. Llorente,
F. Algaba, J. Palou, J. N'Dow, M. Babjuk, T. van der Kwast en
R. Sylvester
Amsterdam UMC, Vrije Universiteit Amsterdam, Amsterdam

\section{Introductie}

Papillary Urothelial Neoplasm of Low Malignant Potential (PUN-LMP) werd in 1998 geïntroduceerd als een niet-invasieve, niet-maligne papillaire laesie. PUN-LMP werd bevestigd als aparte graderingscategorie in de World Health Organization (WHO) 2004- en 2016-classificaties voor blaastumoren.

\section{Materiaal en methoden}

We vergeleken de incidentie van PUN-LMP over een periode van 20 jaar en vergeleken de prognostische waarde van PUN-LMP met laaggradig (LG) en hooggradig (HG) Ta-blaaskanker. De intraobservervariabiliteit van de WHO2004/2016-classificatie (PUN-LMP, LG en HG) werd gerapporteerd voor 314 Ta-T1-tumoren die op twee tijdspunten (2004 en 2018) werden beoordeeld door dezelfde patholoog. Recidief en progressie per WHO2004/2016-graderingscategorie werden geanalyseerd met Kaplan-Meier en multivariabele Cox-regressieanalyses.

\section{Resultaten}

Er zijn individuele data van 3311 patiënten met primaire Ta-blaastumoren uit 17 centra in Europa en Canada. Hiervan werd 3,8\% (127/3311) gediagnosticeerd als PUN-LMP. De incidentie van PUN-LMP nam aanzienlijk af over de tijd, van 31,3\% (1990-2000) naar 3,2\% (2000-2010) en naar $1,1 \%$ (2010-2019). De patholoog die dezelfde coupes twee keer beoordeelde, vond 71/314 (22,6\%) PUN-LMPs in 2004 en 20/314 (6,4\%) in 2018. Er was geen statistisch significant verschil in recidief tussen alle WHO2004/2016-graderingscategorieën (log-rank; $p=0,652$ ), ook niet tussen PUN-LMP en LG: hazard ratio (HR) 0,89 (95\%-BI $=0,69$

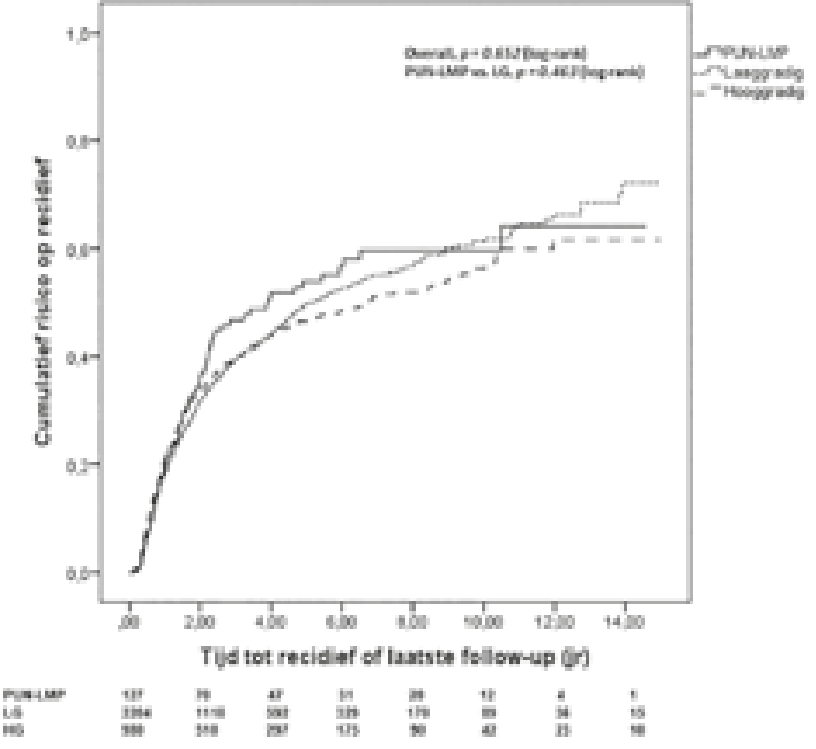

Figuur 20.1 Kaplan-Meier-curves met recidiefrisico voor 3.311 primaire Ta-tumoren per WHO2004/2016-graderingscategorie. De WHO2004/2016-classificatie (PUN-LMP, LG en HG) van 163 Ta-tumoren werd twee keer beoordeeld door dezelfde patholoog, te weten in 2004 en 2018. In deze figuur is de WHO2004/2016-classificatie van de eerste ronde geïncludeerd. De curve en significantie verschilden niet wezenlijk van deze figuur bij gebruik van de tweede ronde.

1,$15 ; p=0,388$, multivariabel). De overall $p$-waarde voor progressie was statistisch significant (log-rank, $p<0,001$ ), maar er was geen verschil in progressie tussen PUN-LMP en LG: HR 0,69 (95\%-BI = 0,28-1,75; $\mathrm{p}=0,438$, multivariabel). Zie figuur 20.1 .

\section{Conclusie}

Vanwege de steeds lagere incidentie van PUN-LMP en de vergelijkbare prognose van PUN-LMP- en Ta-LG-carcinomen, dient de WHO2016-classificatie met PUN-LMP als aparte Ta-graderingscategorie heroverwogen te worden, waarbij het niet zinvol lijkt PUN-LMP als aparte graderingscategorie te handhaven.

\section{De meerwaarde van PET/CT ten opzichte van conventionele CT-thorax/abdomen bij de stadi- ering van invasieve blaaskanker}

C.S. Voskuilen, E.J. van Gennep, E. Vegt, M.L. Donswijk, E.E. Fransen van de Putte, H.G. van der Poel, S. Horenblas, K. Hendricksen, B.W.G. van Rhijn en L.S. Mertens Antoni van Leeuwenhoek, Amsterdam

\section{Introductie}

Stadiëring van patiënten met spierinvasief blaascarcinoom 
cer bohn

9) stafleu

van loghum

bohn

stafleu

van loghum

bohn

stafleu

- van loghum
CCS bohn
8 stafleu
L van loghum

$\sum\left\{\begin{array}{l}\text { bohn } \\ \text { stafleu } \\ \text { van loghum }\end{array}\right.$ $\int S \begin{aligned} & \text { bohn } \\ & \text { stafleu }\end{aligned}$

van loghum

CSe bohn

Stafleu cef bohn

Ptufleu

van loghum cef bohn

8 stafleu

van loghum cec bohn

stafleu

van loghum

\section{bohn}

stafleu
van loghur

$\int$ bohn

stafleu

van loghum

cCehn bohn

stafleu

CL van loghum

cer bohn

9) stafleu

van loghum

bohn

stafleu

van loghum

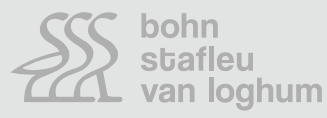

CCS bohn

stafleu

van loghum

\section{gedru}

een

SSS $\begin{aligned} & \text { bohn } \\ & \text { stafleu }\end{aligned}$

van loghum

$\int S \int \begin{aligned} & \text { bohn } \\ & \text { stafleu } \\ & \text { van logh }\end{aligned}$

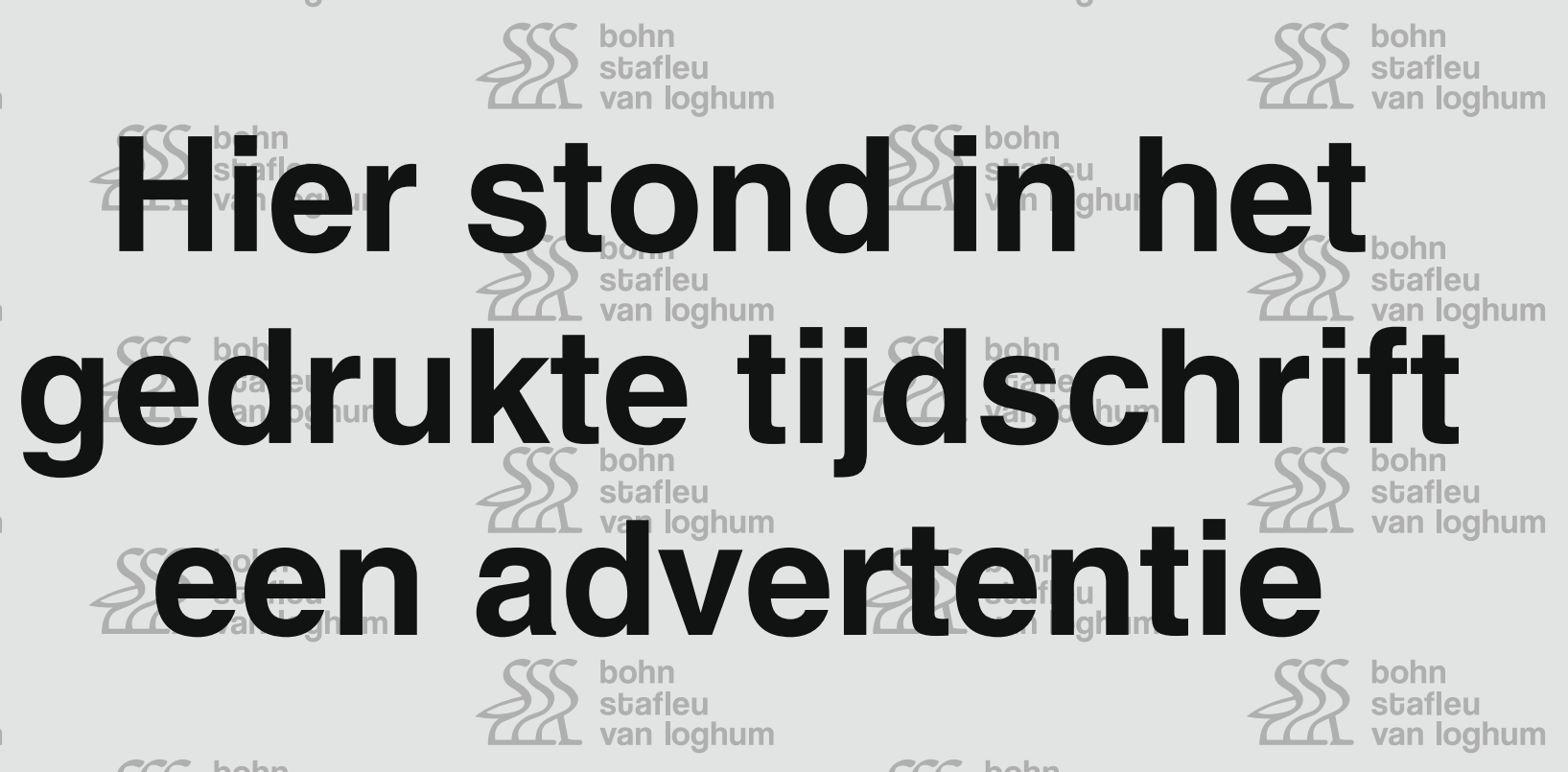

cef bohn

stafleu

van loghum

CSS bohn

stafleu

van loghum

SCS bohn

8 stafleu

van loghum

SSS bohn

van loghum

CSe bohn

8 stafleu

L van loghum

$\iint \begin{aligned} & \text { bohn } \\ & \text { stafleu }\end{aligned}$

van loghum

SSS bohn

van loghum

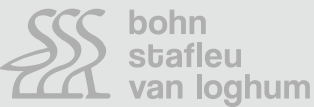

SSS bohn

van loghum

SCS bohn

S) stafleu

1 . van loghum

CCS bohn

bohn
stafleu

CL van loghum van loghum

SS bohn

SS stafleu

SSS $\begin{aligned} & \text { bohn } \\ & \text { stafleu } \\ & \text { van }\end{aligned}$

van loghum

SSS $\begin{aligned} & \text { bohn } \\ & \text { stafleu } \\ & \text { van loghur }\end{aligned}$

van loghum

SCS bohn

$\iint$ stafleu

L van loghum

SSS $\begin{aligned} & \text { bohn } \\ & \text { stafleu }\end{aligned}$

(1 van loghum

SSS $\begin{aligned} & \text { bohn } \\ & \text { stafleu } \\ & \text { van }\end{aligned}$

van loghum

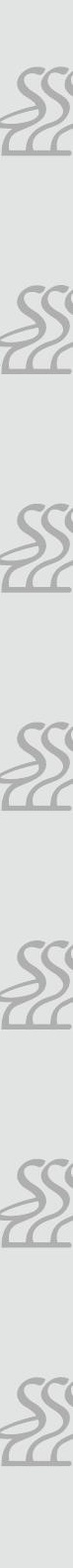

CCS bohn

8) stafleu

van loghum

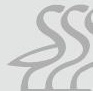

SCS bohn

$9 \int$ strafleu

. van loghum

CSS bohn

$8 \int$ stafleu 
cer bohn

9) stafleu

van loghum

bohn

stafleu

van loghum

bohn

stafleu

- van loghum
CCS bohn
8 stafleu
L van loghum

$\sum\left\{\begin{array}{l}\text { bohn } \\ \text { stafleu } \\ \text { van loghum }\end{array}\right.$ $\int S \begin{aligned} & \text { bohn } \\ & \text { stafleu }\end{aligned}$

van loghum

CSe bohn

Stafleu cef bohn

Ptufleu

van loghum cef bohn

8 stafleu

van loghum cec bohn

stafleu

van loghum

\section{bohn}

stafleu
van loghur

$\int$ bohn

stafleu

van loghum

cCehn bohn

stafleu

CL van loghum

cer bohn

9) stafleu

van loghum

bohn

stafleu

van loghum

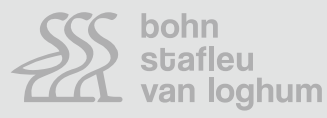

CCS bohn

stafleu

van loghum

\section{gedru}

een

SSS $\begin{aligned} & \text { bohn } \\ & \text { stafleu }\end{aligned}$

van loghum

$\int S \int \begin{aligned} & \text { bohn } \\ & \text { stafleu } \\ & \text { van logh }\end{aligned}$

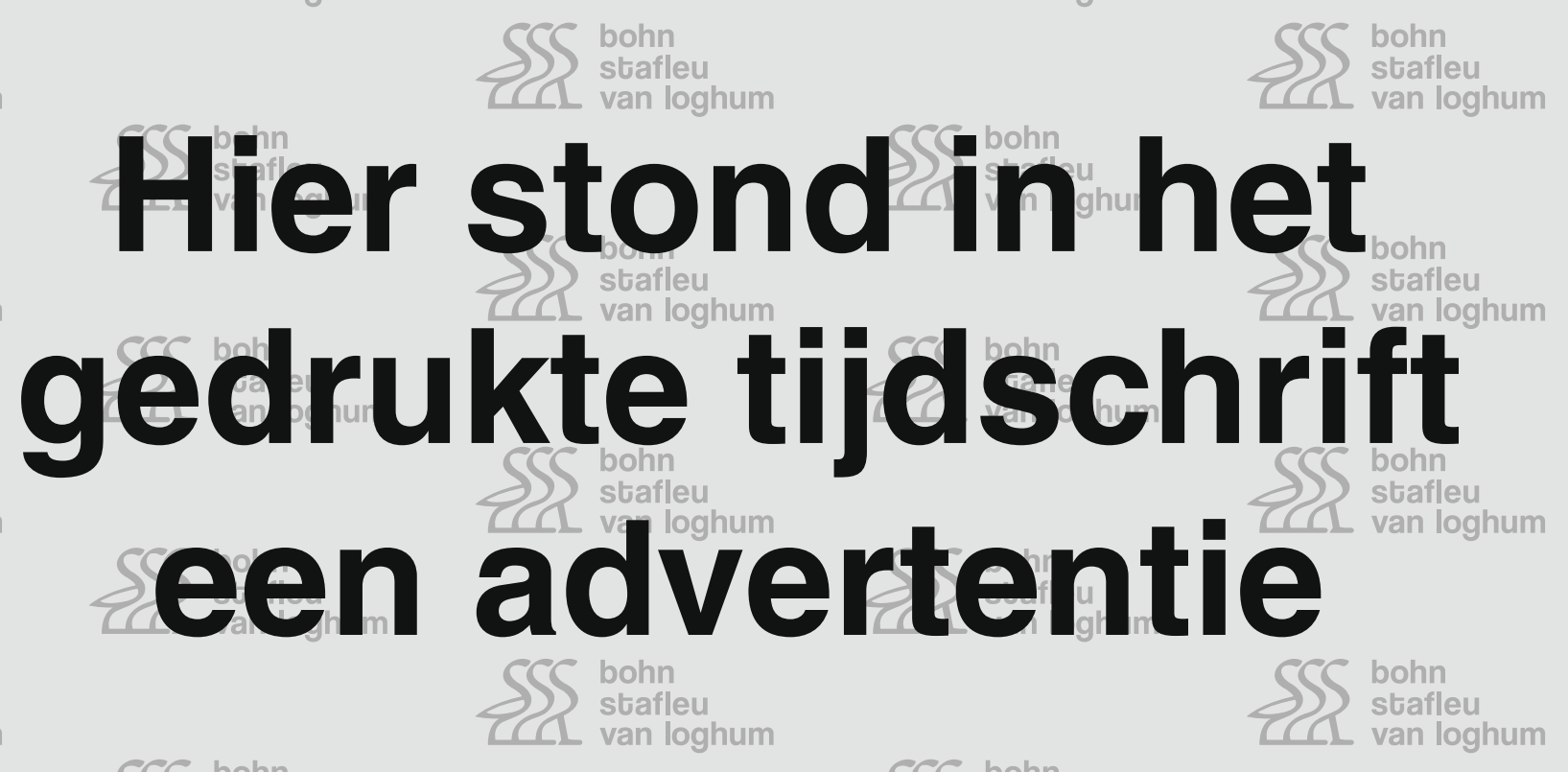

cef bohn

stafleu

van loghum

CSS bohn

stafleu

van loghum

SCS bohn

8 stafleu

van loghum

SSS bohn

van loghum

CSe bohn

8 stafleu

L van loghum

$\iint \begin{aligned} & \text { bohn } \\ & \text { stafleu }\end{aligned}$

van loghum

SSS bohn

van loghum

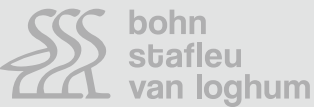

SSS bohn

van loghum

SCS bohn

S) stafleu

1 . van loghum

CCS bohn

bohn
stafleu

CL van loghum van loghum

SS bohn

SS stafleu

SSS $\begin{aligned} & \text { bohn } \\ & \text { stafleu } \\ & \text { van }\end{aligned}$

van loghum

SSS $\begin{aligned} & \text { bohn } \\ & \text { stafleu } \\ & \text { van loghur }\end{aligned}$

van loghum

SCS bohn

$\iint$ stafleu

L van loghum

SSS $\begin{aligned} & \text { bohn } \\ & \text { stafleu }\end{aligned}$

(1 van loghum

SSS $\begin{aligned} & \text { bohn } \\ & \text { stafleu } \\ & \text { van }\end{aligned}$

van loghum

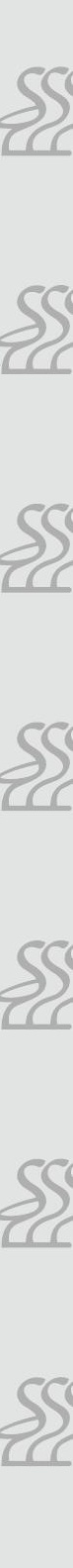

CCS bohn

8) stafleu

van loghum

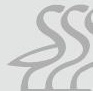

SCS bohn

$9 \int$ strafleu

. van loghum

CSS bohn

$8 \int$ stafleu 
cer bohn

9) stafleu

van loghum

bohn

stafleu

van loghum

bohn

stafleu

- van loghum
CCS bohn
8 stafleu
L van loghum

$\sum\left\{\begin{array}{l}\text { bohn } \\ \text { stafleu } \\ \text { van loghum }\end{array}\right.$ $\int S \begin{aligned} & \text { bohn } \\ & \text { stafleu }\end{aligned}$

van loghum

CSe bohn

Stafleu cef bohn

Ptufleu

van loghum cef bohn

8 stafleu

van loghum cec bohn

stafleu

van loghum

\section{bohn}

stafleu
van loghur

$\int$ bohn

stafleu

van loghum

cCehn bohn

stafleu

CL van loghum

cer bohn

9) stafleu

van loghum

bohn

stafleu

van loghum

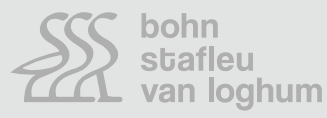

CCS bohn

stafleu

van loghum

\section{gedru}

een

SSS $\begin{aligned} & \text { bohn } \\ & \text { stafleu }\end{aligned}$

van loghum

$\int S \int \begin{aligned} & \text { bohn } \\ & \text { stafleu } \\ & \text { van logh }\end{aligned}$

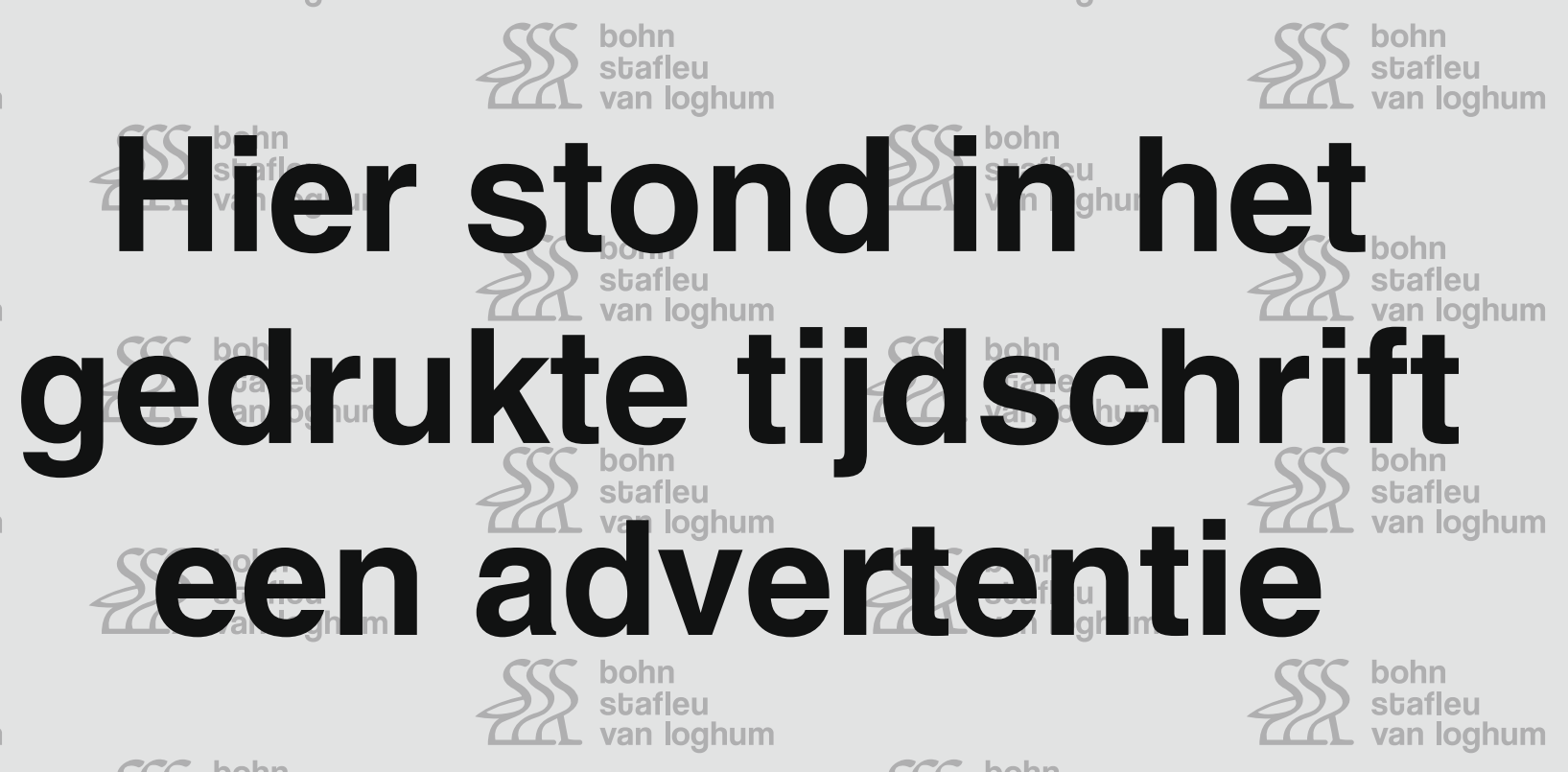

cef bohn

stafleu

van loghum

CSS bohn

stafleu

van loghum

SCS bohn

8 stafleu

van loghum

SSS bohn

van loghum

CSe bohn

8 stafleu

L van loghum

$\iint \begin{aligned} & \text { bohn } \\ & \text { stafleu }\end{aligned}$

van loghum

SSS bohn

van loghum

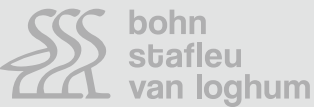

SSS bohn

van loghum

SCS bohn

S) stafleu

1 . van loghum

CCS bohn

bohn
stafleu

CL van loghum van loghum

SS bohn

SS stafleu

SSS $\begin{aligned} & \text { bohn } \\ & \text { stafleu } \\ & \text { van }\end{aligned}$

van loghum

SSS $\begin{aligned} & \text { bohn } \\ & \text { stafleu } \\ & \text { van loghur }\end{aligned}$

van loghum

SCS bohn

$\iint$ stafleu

L van loghum

SSS $\begin{aligned} & \text { bohn } \\ & \text { stafleu }\end{aligned}$

(1 van loghum

SSS $\begin{aligned} & \text { bohn } \\ & \text { stafleu } \\ & \text { van }\end{aligned}$

van loghum

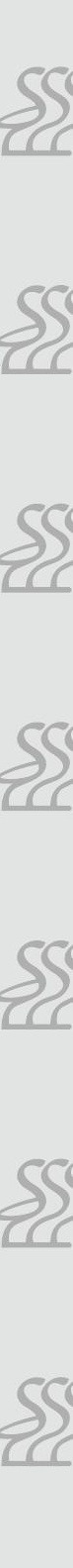

CCS bohn

8) stafleu

van loghum

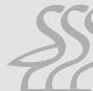

SCS bohn

$9 \int$ strafleu

. van loghum

CSS bohn

$8 \int$ stafleu 
cer bohn

9) stafleu

van loghum

bohn

stafleu

van loghum

bohn

stafleu

- van loghum
CCS bohn
8 stafleu
L van loghum

$\sum\left\{\begin{array}{l}\text { bohn } \\ \text { stafleu } \\ \text { van loghum }\end{array}\right.$ $\int S \begin{aligned} & \text { bohn } \\ & \text { stafleu }\end{aligned}$

van loghum

CSe bohn

Stafleu cef bohn

Ptufleu

van loghum cef bohn

8 stafleu

van loghum cec bohn

stafleu

van loghum

\section{bohn}

stafleu
van loghur

$\int$ bohn

stafleu

van loghum

cCehn bohn

stafleu

CL van loghum

cer bohn

9) stafleu

van loghum

bohn

stafleu

van loghum

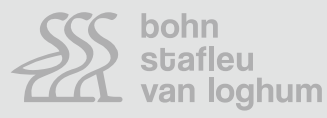

CCS bohn

stafleu

van loghum

\section{gedru}

een

SSS $\begin{aligned} & \text { bohn } \\ & \text { stafleu }\end{aligned}$

van loghum

$\int S \int \begin{aligned} & \text { bohn } \\ & \text { stafleu } \\ & \text { van logh }\end{aligned}$

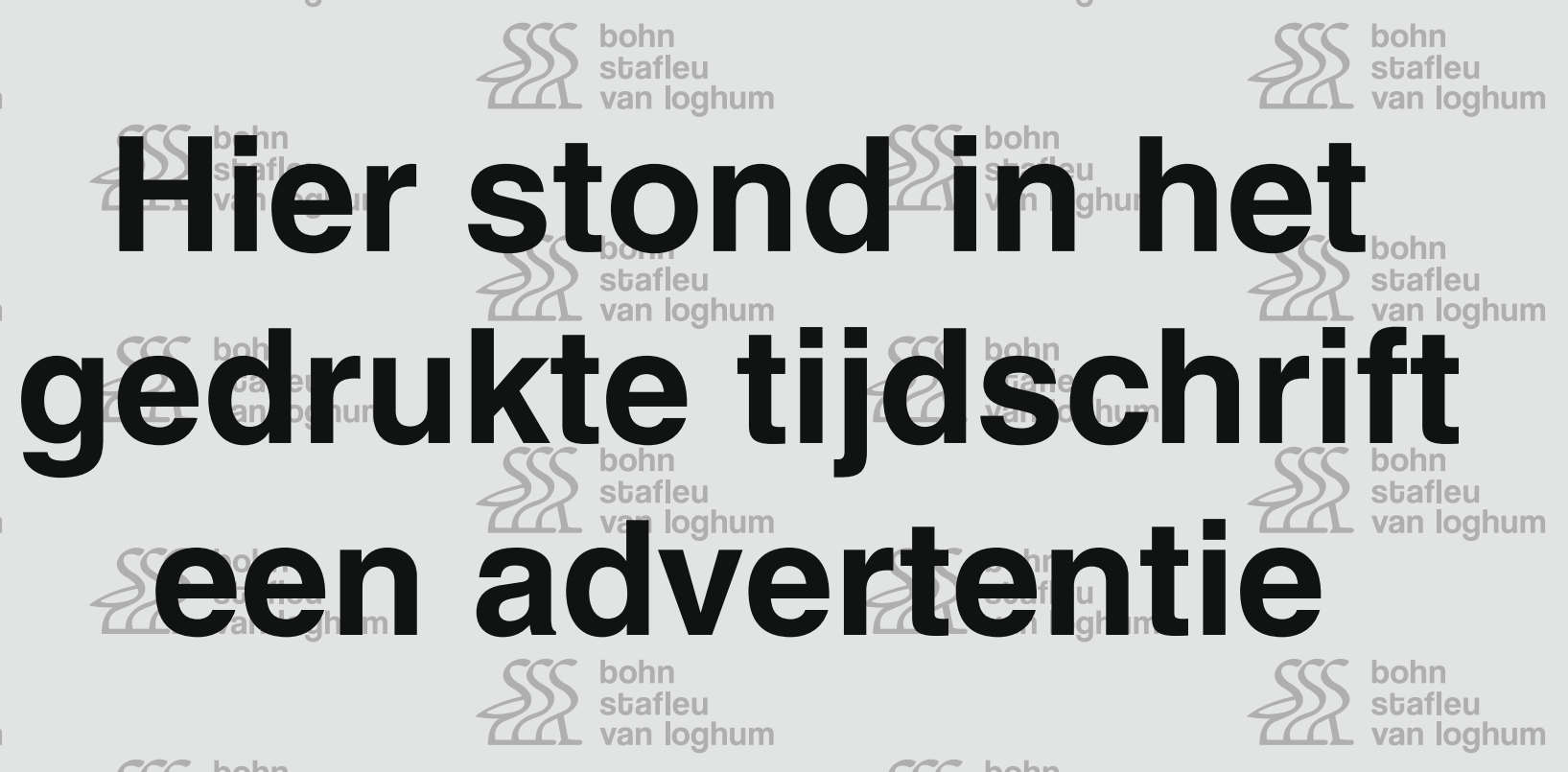

cef bohn

stafleu

van loghum

CSS bohn

stafleu

van loghum

SCS bohn

8 stafleu

van loghum

SSS bohn

van loghum

CSe bohn

8 stafleu

L van loghum

$\iint \begin{aligned} & \text { bohn } \\ & \text { stafleu }\end{aligned}$

van loghum

SSS bohn

van loghum

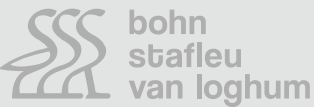

SSS bohn

van loghum

SCS bohn

S) stafleu

1 . van loghum

CCS bohn

bohn
stafleu

CL van loghum van loghum

SS bohn

SS stafleu

SSS $\begin{aligned} & \text { bohn } \\ & \text { stafleu } \\ & \text { van }\end{aligned}$

van loghum

SSS $\begin{aligned} & \text { bohn } \\ & \text { stafleu } \\ & \text { van loghur }\end{aligned}$

van loghum

SCS bohn

$\iint$ stafleu

L van loghum

SSS $\begin{aligned} & \text { bohn } \\ & \text { stafleu }\end{aligned}$

(1 van loghum

SSS $\begin{aligned} & \text { bohn } \\ & \text { stafleu } \\ & \text { van }\end{aligned}$

van loghum

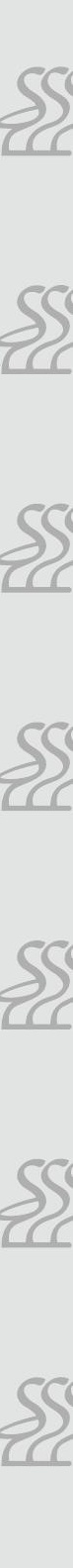

CCS bohn

8) stafleu

van loghum

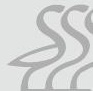

SCS bohn

$9 \int$ strafleu

. van loghum

CSS bohn

$8 \int$ stafleu 
(MIBC) geschiedt volgens de EAU-richtlijn middels CT-thorax/abdomen. Op onze blaaskankerpolikliniek wordt sinds 2011 daarnaast standaard een FDG-PET/CT-scan verricht. In deze studie onderzochten we de meerwaarde van $\mathrm{PET} / \mathrm{CT}$ ten opzichte van conventionele CT bij de stadiëring van MIBC.

\section{Materiaal en methoden}

Alle opeenvolgende patiënten die een PET/CT-scan ondergingen in verband met stadiëring van spierinvasief blaascarcinoom tussen 1 januari 2011 en 1 januari 2019 werden geincludeerd. Patiënten waren voorafgaand (in verwijzend ziekenhuis of in ons ziekenhuis) gestadieerd met een diagnostische CT-thorax/abdomen. Het klinische tumorstadium voor en na de PET/CT-scan werd bepaald volgens de TNM-classificatie (2017), evenals de voorkeursbehandeling: (1) lokale curatieve behandeling (cystectomie, chemoradiatie, brachytherapie), (2) neoadjuvante/inductie chemotherapie (NAIC) gevolgd door lokale behandeling of (3) palliatie.

\section{Resultaten}

Er werden 642 patiënten geïncludeerd (gem. leeftijd 65 jaar). De mediane tijd tussen de diagnostische CT- en de PET/CTscan was 27 dagen (interkwartielafstand 10-41 dagen). Bij $30 \%$ van de patiënten was het tumorstadium voor en na de PET/CT-scan verschillend. PET/CT leidde vaker tot upstaging dan downstaging ( $28 \%$ vs. 2,2\%). Hierdoor veranderde de voorkeursbehandeling van 120/642 (19\%) patiënten: 64 (10\%) patiënten die gepland waren voor lokale behandeling werden geselecteerd voor NAIC en bij $56(8,7 \%)$ patiënten werd op basis van 'nieuwe' metastasen op de PET/CT-scan van curatieve behandeling afgezien. De PET/CT-scan detecteerde een tweede primaire maligniteit bij $31(4,8 \%)$ patiënten. Hierdoor veranderde de behandeling van het blaascarcinoom bij nog eens 14/642 (2,2\%) patiënten. Indien een additionele laesie leidde tot een beleidsverandering, dan werd deze in de meeste gevallen histopathologisch bevestigd.

\section{Conclusie}

Beeldvorming met FDG-PET/CT levert aanvullende stadieringsinformatie op ten opzichte van conventionele CT. Hierdoor verandert de behandeling van $1 / 5$ van de patiënten met spierinvasief blaascarcinoom. PET/CT kan patiëntenselectie voor NAIC verbeteren en tevens niet-geïndiceerde cystectomieën voorkomen.

\section{Transurethrale resectie van niet-spierinvasief urotheelcelcarcinoom van de blaas met fluor- escentie en wit-licht-cystoscopie: recidiefkans in een groot opleidingsziekenhuis}

\author{
F.J.S. Hoogeveen, M.H. Blanker, E.C.C. Cauberg en M.G. Steffens \\ Isala, Zwolle
}

\section{Introductie}

Bij een transurethrale resectie (TUR) voor urotheelcelcarcinoom (UCC) van de blaas is gebruik van wit licht (WL) de gouden standaard. Fluorescentiecystoscopie (FC) is ontwikkeld om de detectie van UCC te verbeteren, maar heeft in de literatuur tegenstrijdige uitkomsten wat betreft het effect op de recidiefkans. Wij vergeleken de recidiefkans tussen FCTUR en WL-TUR op korte en lange termijn.

\section{Materiaal en methoden}

In deze retrospectieve studie includeerden wij 288 patiënten die van 2009-2012 vanwege niet-spierinvasief UCC een radicale TUR ondergingen. Tot 2011 werden patiënten standaard behandeld met WL en daarna met FC $(n=140)$. Alle patiënten ondergingen postoperatief een mitomycine-c-instillatie en op indicatie ook adjuvante instillaties met mitomycine c of BCG. Patiënten ondergingen gestructureerde follow-up middels poliklinische cystoscopie met WL gedurende vijf jaar. Primaire uitkomstmaat was het eerste histologisch bewezen recidief. Wij berekenden de tijd tot recidief en de recidiefkans na zes maanden en na één en vijf jaar. Ten slotte vergeleken wij de recidiefvrije overleving na vijf jaar van beide groepen met een Cox-regressieanalyse, waarbij met propensity scores is gecorrigeerd voor verschillen in tumorgraad, tumorstadium, aantal laesies bij TUR, aanwezigheid van CIS en primair of recidief UCC bij inclusie.

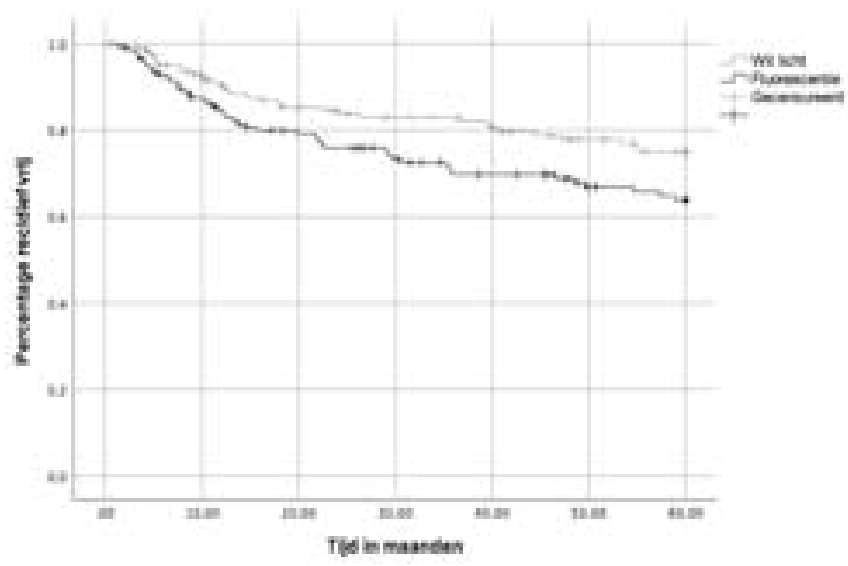

Figuur 22.1 Recidiefkans van wit licht versus fluoriscentiecystoscopie 


\section{Resultaten}

De gemiddelde tijd tot recidief in vijf jaar was 50,6 maanden $(95 \%$-BI $=47,6-53,8)$ bij WL en 45,9 $(95 \%$-BI $=42,2-$ $53,8 ; p=0,047)$ bij FC, zie figuur 22.1. De recidiefkans na zes maanden was $8,8 \%$ bij WL en $9,3 \%$ bij FC $(p=0,86)$. $\mathrm{Na}$ één jaar was dit respectievelijk $13,6 \%$ en $18,6 \%(p=$ $0,263)$. De recidiefkans na vijf jaar was groter bij FC $(32,1 \%)$ dan in de WL-groep $(19,7 \%)$. Cox-regressieanalyse toonde een hogere recidiefkans bij FC (HR $=1,59$; 95\%$\mathrm{BI}=1,01-2,50)$, gecorrigeerd met propensity score 1,82 $(95 \%-\mathrm{BI}=1,12-2,94 ; p=0,012)$.

\section{Conclusie}

De recidiefkans van niet-spierinvasief UCC verschilde tussen wit-licht- en fluorescentie-TUR niet op korte termijn. $\mathrm{Na}$ vijf jaar bleek, ook na correctie voor mogelijke confounders, de recidiefkans groter bij behandeling met fluorescentiecystoscopie.

\section{FGFR3-mutatie versus $F G F R 3$-expressie in relatie tot klinisch-pathologische uitkomsten in een groot cystectomiecohort: implicaties voor anti-FGFR3-blaaskankerbehandeling}

L.S. Mertens, T.C. Zuiverloon, R. Mayr, P.J. Bostrom, M. Marquez, E.C. Zwarthoff, J.L. Boormans, C.S. Abas, G.J. van Leenders, Y. Neuzillet, M.S. van der Heijden, F.X. Real, R. Stohr, A.R. Zlotta, M. Eckstein, Y. Soorojebally, M. Burger, F. Radvanyi, N. Sirab, T. van der Kwast, N. Malats, A. Hartmann, Y. Allory en B.W. van Rhijn

Antoni van Leeuwenhoek, Amsterdam

\section{Introductie}

FGFR3-mutaties worden met name gevonden in laaggradige, niet-invasieve blaaskanker (BC). Bij spierinvasieve BC komt de FGFR3-mutatie veel minder vaak voor. Wel wordt bij $40 \%$ van de spierinvasieve BC FGFR3-overexpressie zonder FGFR3-mutatie gevonden. We onderzochten de relatie tussen FGFR3-mutatie en FGFR3-expressie en de invloed op klinisch-pathologische uitkomsten in een internationaal radicale cystectomie (RC) cohort.

\section{Materiaal en methoden}

We includeerden 1000 cN0M0 chemotherapie-naïeve-BC-patiënten die een RC ondergingen. Aan de hand van HE-coupes werden paraffineblokjes met tumor verzameld waarvan DNA werd geïsoleerd. In zeven laboratoria werd met PCR-SNaPshot de FGFR3-mutatiestatus onderzocht. Expressie van FGFR3 en P53 werd bepaald met immunohistochemie. De associatie tussen de FGFR3-mutatie, FGFR3-expressie, P53 en klinisch-pathologische variabelen (pT, graad, CIS, P53-expressie (cut-off $>10 \%$ ) en $\mathrm{pN}$ werden onderling en met ziektevrije overleving (DSS) vergeleken.

\section{Resultaten}

Bij 107/1000 (11\%) tumoren werden FGFR3-mutaties gevonden, 67 keer S249C. FGFR3-overexpressie was anwezig bij 279/1000 (28\%); aberrante P53-expressie bij 69\%. Van de FGFR3-mutante tumoren had 73\% FGFR3-overexpressie $v s .22 \%$ van de wildtype tumoren. FGFR3-mutaties waren geassocieerd met lager pT-stadium, G2, pN0, normaal P53 (alle $p<0,001)$, afwezigheid van CIS $(p=0,009)$ en langere DSS $(p=0,001)$. FGFR3-overexpressie was geassocieerd met lager pT-stadium en G2 (beide $p<0,001$ ), maar niet met afwezigheid van CIS, normaal P53, pN0 en ook niet met langere DSS $(p=0,204)$. Bij de patiënten met FGFR3-mutante tumoren vonden we geen verschil in DSS tussen normale FGFR3-expressie vs. overexpressie ( $p=$ 0,444). Bij de FGFR3-wildtype tumoren bestond dit verschil ook niet.

\section{Conclusie}

De FGFR3-mutatie identificeert patiënten met een relatief gunstige prognose na RC. FGFR3-overexpressie in wildtype tumoren heeft geen invloed op de overleving. Dit suggereert dat de FGFR3-mutatie een 'driver' is en FGFR3expressie een 'bystander'. Mogelijk hebben vooral patiënten met FGFR3-mutaties baat bij anti-FGFR3-therapie en met alléén FGFR3-overexpressie niet.

\section{Heeft sacrale neuromodulatie een effect op het aandrangsgevoel bij patiënten met niet- obstructieve urineretentie?}

M. Reekmans, A. Herrewegh, T. Marcelissen, G. van Koeveringe, D. Vrijens en Ph. Van Kerrebroeck

Maastricht Universitair Medisch Centrum+, Maastricht

\section{Introductie}

Blaassensaties bij patiënten met niet-obstructieve urineretentie (NOR), in het bijzonder bij patiënten met niet-neurogene blaasdisfunctie, zijn nog niet goed onderzocht. Sacrale neuromodulatie (SNM) behoort tot de behandelopties bij deze patiëntengroep. Tijdens teststimulatie zien we in de praktijk vaak blaassensatie terugkeren, echter, het exacte effect van SNM op het aandrangsgevoel en de invloed hiervan op de uitkomst van de teststimulatie, blijft onduidelijk. Het doel van onze studie was om te bepalen of SNM het aandrangsgevoel bij NOR-patiënten met niet-neurogene blaasdisfunctie verandert.

\section{Materiaal en methoden}

We analyseerden sensation-related bladder diaries (SR-BDs) 
Tabel 24.1 SR-BD-parameters bij aanvang van de testfase versus teststimulatie

\begin{tabular}{|c|c|c|c|c|c|}
\hline \multirow[t]{8}{*}{$\begin{array}{l}\text { succesvol } \\
n=16\end{array}$} & & & $\begin{array}{l}\text { baseline } \\
(\text { gem. } \pm \mathrm{SD})\end{array}$ & $\begin{array}{l}\text { testfase } \\
(\text { gem. } \pm \mathrm{SD})\end{array}$ & $p$-waarde \\
\hline & \multicolumn{2}{|l|}{ mictievolume $(\mathrm{ml})$} & $160 \pm 100$ & $244 \pm 101$ & $\underline{0,028}$ \\
\hline & \multicolumn{2}{|l|}{ katheterisatie volume $(\mathrm{ml})$} & $266 \pm 158$ & $157 \pm 186$ & $\underline{0,021}$ \\
\hline & \multicolumn{2}{|l|}{ urge bij $100 \mathrm{ml}$} & $0,5 \pm 0,7$ & $0,5 \pm 0,3$ & 0,779 \\
\hline & \multirow[t]{4}{*}{ blaasvullingsgevoel $/ 100 \mathrm{ml}$} & urge 0 & $1,7 \pm 1,4$ & $2,0 \pm 1,1$ & 0,683 \\
\hline & & urge 1 & $3,5 \pm 5,4$ & $2,9 \pm 1,8$ & 0,859 \\
\hline & & urge 2 & $3,1 \pm 3,0$ & $2,2 \pm 1,2$ & 0,400 \\
\hline & & urge 3 & $1,7 \pm 0,4$ & $1,4 \pm 0,8$ & 0,553 \\
\hline \multirow{7}{*}{$\begin{array}{l}\text { niet succesvol } \\
n=24\end{array}$} & \multicolumn{2}{|l|}{ mictievolume $(\mathrm{ml})$} & $89 \pm 59$ & $105 \pm 95$ & 0,594 \\
\hline & \multicolumn{2}{|l|}{ katheterisatievolume $(\mathrm{ml})$} & $325 \pm 114$ & $329 \pm 100$ & 0,903 \\
\hline & \multicolumn{2}{|l|}{ urge bij $100 \mathrm{ml}$} & $0,7 \pm 0,8$ & $0,6 \pm 0,6$ & 0,801 \\
\hline & \multirow[t]{4}{*}{ blaasvullingsgevoel/100 ml } & urge 0 & $1,7 \pm 0,6$ & $1,8 \pm 1,2$ & 0,850 \\
\hline & & urge 1 & $2,5 \pm 2,0$ & $2,5 \pm 2,1$ & 0,345 \\
\hline & & urge 2 & $3,5 \pm 2,8$ & $3,6 \pm 3,1$ & 0,850 \\
\hline & & urge 3 & $3,5 \pm 3,3$ & $3,0 \pm 2,6$ & 0,733 \\
\hline
\end{tabular}

van NOR-patiënten die een teststimulatie ondergingen met een tined lead procedure tussen januari 2016 en augustus 2018. Patiënten vulden gedurende drie opeenvolgende dagen een SR-BD in, zowel bij aanvang van de testfase als na twee weken. Een SR-BD bevat een visueel analoge schaal om de perceptie van blaasvulling te scoren en daarnaast ook een vierpuntsaandrangsscore. Op basis hiervan berekenden we een ratio voor de perceptie van blaasvulling en aandrang per $100 \mathrm{ml}$ voor elke mictie.

\section{Resultaten}

In totaal evalueerden we 1.148 micties van 40 patiënten met NOR waarvan 16 een succesvolle testfase kenden. Patiënten met een succesvolle testfase $(\mathrm{T}+)$, plasten met grotere volumes en rapporteerden kleinere volumes bij katheterisatie tijdens teststimulatie vergeleken met de volumes bij aanvang van de testfase. Voor patiënten met een niet-succesvolle testfase ( $\mathrm{T}-$ ) gold dit principe niet. Echter, zowel $\mathrm{T}+-$ als $\mathrm{T}$--patiënten rapporteerden geen verandering in aandrangsen blaasvullingsgevoel tijdens de testfase. Uiteindelijk moesten 12 van de $16 \mathrm{~T}+$-patiënten helemaal niet meer katheteriseren of rapporteerden ze een daling van $70 \%$ in het residu na mictie. Zie tabel 24.1.

\section{Conclusie}

Deze resultaten tonen dat het aandrangsgevoel bij patiënten met NOR niet verandert door SNM. Daarnaast lijkt het opnieuw tot mictie komen bij patiënten met een succesvolle testfase niet afhankelijk te zijn van een verandering in het aandrangsgevoel.

\section{Hersengebieden die zijn betrokken bij de aansturing van de bekkenbodem. Een 7-Tesla fMRI-studie}

I.M. Groenendijk, S.P.R. Luijten, W. van der Zwaag, J.C. Holstege, J.R. Scheepe, C.I. de Zeeuw en B.F.M. Blok Erasmus MC, Rotterdam

\section{Introductie}

Bekkenbodemdisfuncties hebben een hoge prevalentie bij mannen en vrouwen. De literatuur toont aan dat disfunctioneren van het zenuwstelsel een belangrijke rol speelt bij bekkenbodemklachten. De centrale aansturing van de bekkenbodem is onderzocht middels verschillende technieken, waaronder PET-, 1,5T- en 3T-functionele MRI (fMRI). De klinische waarde voor het individu van dit hersenonderzoek is beperkt, vanwege de groepsanalyse. Het analyseren van resultaten op individueel niveau is voor de centrale bekkenbodemaansturing nooit gepubliceerd. Het doel van deze studie is om de hersengebieden die zijn betrokken bij het aansturen van de bekkenbodem beter in kaart te brengen op individueel niveau en deze te vergelijken met de groepsresultaten.

\section{Materiaal en methoden}

Zeventien gezonde mannen ondergingen een 7T-fMRI terwijl zij twee taken uitvoerden: repetitief aanspannen van de bekkenbodem en als controletaak het horizontaal bewegen van de tong. Resultaten in het gehele brein werden bekeken, en op de cortex en het cerebellum werd de groepsanalyse vergeleken met de individuele resultaten. Ook werd er een connectiviteitsanalyse gedaan van de betrokken hersengebieden. 


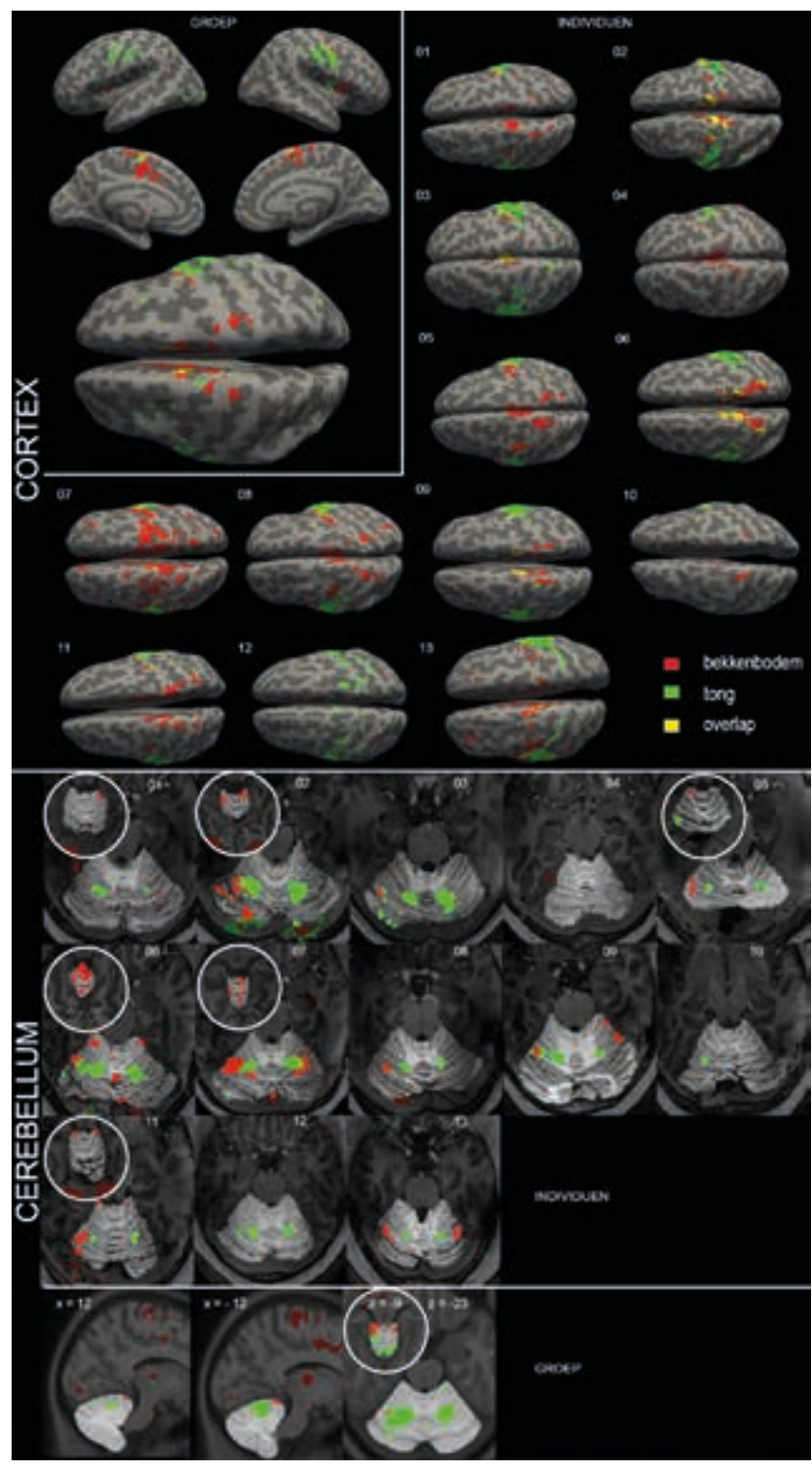

Figuur 25.1

\section{Resultaten}

Figuur 25.1 toont de resultaten van de groepsanalyse en van 13 individuen. Van vier mannen konden de resultaten niet beoordeeld worden wegens bewegingsartefacten. De gebieden die actief werden tijdens het aanspannen van de bekkenbodem waren de primaire motorische cortex, de supplementaire motor cortex, de gyrus cinguli, het putamen, de thalamus, de insula en het cerebellum. De connectiviteitsanalyse toonde een significante verbindingen van specifieke motorgerelateerde gebieden corticaal en subcorticaal tijdens het aanspannen van de bekkenbodem.

\section{Conclusies}

Deze studie heeft de hersengebieden die zijn betrokken bij de aansturing van de bekkenbodem gedefinieerd en laten zien dat 7T-fMRI een bruikbare techniek is om de motorische aansturing van de bekkenbodem bij individuen te bekijken. Er is onderzoek opgestart om deze gebieden te valideren bij de individuele patiënt.

\section{Ontkromming met collagenase bij peyronie: niet voor een prikje te koop}

J.J.H. Beck, J.P. Verkerk-Geelhoed en L.J. de Boer

St. Antonius Ziekenhuis, Nieuwegein

\section{Introductie}

Collagenase clostridium histolyticum $(\mathrm{CCH})$ is het enige medicijn dat ooit is geregistreerd voor de behandeling van een kromstand van de penis ten gevolge van de ziekte van Peyronie. Wij presenteren de resultaten van de eerste patiënten in Nederland die volgens het originele registratieschema zijn behandeld.

\section{Materiaal en methoden}

Van 1 januari tot 1 juli 2018 zijn 12 patiënten geïncludeerd conform de IMPRESS-1- en 2-studies: om de zes weken twee doses van $0,9 \mathrm{mg} \mathrm{CCH}$, met steeds 48 à 72 uur tussen de doses, gecombineerd met buig- en strekoefeningen van de penis in de zesweekse herstelperiode. De primaire uitkomstmaten zijn verandering van de curvatuur en de mogelijkheid tot het kunnen verrichten van coïtus. Secundaire uitkomstmaten zijn de gemelde complicaties (Clavien), de pijnscore van de injecties en de antwoorden op tevredenheidsvragen (patient reported outcome measures; PROMs).

\section{Resultaten}

Negen patiënten (75\%) hebben de volledige behandeling van $4 \times 2$ doses doorlopen. Drie patiënten stopten na $2 \times 2$ doses. Redenen waren: pijn, te weinig effect of geen foto willen inleveren. De gemiddelde verbetering in curvatuur is 18 graden (spreiding -4 tot 49 ). Seksueel verkeer lukte bij zes patiënten weer (50\%). De overal gemiddelde pijnscore voor de injecties in de plaque is 3,7 (range $0-8 ; n=63$ ). PROM: de totale tevredenheidsscore van de behandeling was 6,9 (range 6-8;n=9). Alle patiënten zouden de behandeling aan lotgenoten aanbevelen $(n=9)$, ook als ze zelf geen meetbaar effect hadden ondervonden. Seksuele verbetering werd door zeven patiënten (58\%) positief beantwoord. Drie patiënten $(25 \%)$ hadden geen verbetering van de kromstand (0-10\% afname van de curvatuur). Eén patiënt ontwikkelde een wondinfectie, waarvoor hij antibiotische behandeling kreeg (Clavien 2). De overige patiënten ontwikkelden allemaal één of meerdere keren een hematoom van de penis (Clavien 1). 


\section{Conclusie}

Dit zijn de eerste patiënten in Nederland die zijn behandeld met $\mathrm{CCH}$ wegens de ziekte van Peyronie. Conform de introductie-RCT's in de Verenigde Staten is er een respons bij $75 \%$ van de patiënten. De gemiddelde afname is slechts 18 graden, $27 \%$ reductie van kromstand. Seksueel verkeer lukte weer bij de helft van de patiënten.

\section{Neemt detectie van germ cell neoplasia in situ (GCNIS) toe bij de evaluatie van testiculair sperma-extractierestmateriaal van patiënten met niet-obstructieve azoöspermie?}

\author{
E. Jansen, W.P.A. Boellaard, M. Dinkelman-Smit, \\ J.W. Oosterhuis en L.H.J. Looijenga \\ Erasmus MC, Rotterdam
}

\section{Introductie}

Infertiliteit is een risicofactor voor het ontwikkelen van een maligne testiculaire kiemceltumor (TKCT). Het ontstaan wordt altijd voorafgegaan door een voorloperstadium, germ cell neoplasia in situ (GCNIS) genoemd. De prevalentie van GCNIS bij infertiele patiënten varieert in verschillende studies van $0,5-3,5 \%$. Dit verschil wordt met name veroorzaakt door heterogeniteit in de oorzaak van de infertiliteit en gelijktijdig voorkomen van TKCT. Infertiele patiënten, die een testiculaire sperma-extractie (TESE) ondergaan, wordt geadviseerd standaard een biopt te laten verrichten voor histologisch onderzoek naar de aanwezigheid van GCNIS. Het doel van deze studie is retrospectief te onderzoeken of het analyseren van TESE-restmateriaal de detectiekans van GCNIS verhoogt binnen een cohort patiënten met nietobstructieve azoöspermie (NOA).

\section{Materiaal en methoden}

In totaal ondergingen 489 patiënten met azoöspermie een TESE-procedure en een standaardbiopt ter beoordeling van de aanwezigheid van GCNIS. Na de extractie van spermatozoa uit het TESE-biopt werd het resterende materiaal ingevroren op $-80^{\circ} \mathrm{C}$. Ten tijde van het onderzoek werd het restmateriaal ontdooid, gefixeerd in formaline, in paraffine ingebed, gekleurd met OCT3/4 en/of PLAP en vergeleken met de resultaten van de standaardbiopten.

\section{Resultaten}

Met behulp van het TESE-restmateriaal werden geen nieuwe patiënten met GCNIS geïdentificeerd. De sensitiviteit van de OCT3/4- en PLAP-kleuring voor detectie van GCNIS in TESE-restmateriaal is respectievelijk $58 \%$ en $96 \%$; de specificiteit voor beide kleuringen is $100 \%$. De prevalentie van GCNIS is in dit cohort NOA-patiënten is $0,8 \%$.

\section{Conclusie}

De analyse van TESE-restmateriaal met behulp van PLAP als diagnosticum voor GCNIS is valide. Het analyseren van TESE-restmateriaal, ondanks een groter bioptvolume, resulteert niet in een toename van het aantal GCNIS-diagnoses in een cohort NOA-patiënten. Mede door een duidelijk gedefinieerde inclusie is de prevalentie van GCNIS in dit cohort lager dan in de literatuur. Mogelijk moet de counseling van NOA-patiënten die een TESE ondergaan, hierop worden aangepast.

\section{Pijn na midurethrale sling; de rol van meshresectie}

\author{
N. Aourag, B.B. Mengerink, K.B. Kluivers, K.J.B. Notten, \\ J.P.F.A. Heesakkers en F.M.J. Martens \\ Radboudumc, Nijmegen
}

\section{Introductie}

Pijn na een retropubische of transobturatoire midurethrale sling (MUS) heeft vaak een invaliderende impact op het leven van een patiënt. De behandeling kan uitdagend zijn, zeker als er geen zichtbare oorzaken zijn, zoals een erosie/exposure. Doel van deze studie is de plaatsbepaling van MUS-resectie bij patiënten met persisterende pijn.

\section{Materiaal en methode}

$\mathrm{CMO}$-goedgekeurd retrospectief dossieronderzoek aangevuld met een vragenlijst onder vrouwen die tussen november 2004 en juni 2018 één of meerdere ingrepen ondergingen voor partiële of complete resectie van een MUS in verband met persisterende pijn zonder zichtbare afwijkingen. De primaire uitkomstmaat is verbetering in VAS-score (0-10). Secundaire uitkomstmaten zijn onder andere recidiefincontinentie.

\section{Resultaten}

31 patiënten werden geïncludeerd en er werden 24 vragenlijsten ingevuld. De gemiddelde leeftijd bij plaatsing van de MUS is 48 jaar (range 28-65). De periode tussen plaatsing van de MUS tot resectie daalt van mediaan 64 maanden (range 1-141) in 2011 tot mediaan 12 maanden (range 1-54) na $2011(p=0,001)$. Uit de vragenlijsten bleek een mediane follow-up van 25 (range 5-104) maanden. De gemiddelde VAS-score daalde van 8,1 (range 0-10) preoperatief naar $4,6$ (range $2-10)$ postoperatief $(p<0,000) ; 25 \%$ VAS $=0$. Patiënten met eenzijdige vaginale resectie $(n=11)$ hadden een daling op de VAS van 5,6 ( $p=0,003)$ ten opzichte van $2,9(p=0,149)$ bij patiënten met een complete vaginale resectie $(n=10)$. Er werden geen voorspellende factoren voor pijnreductie aangetoond. Uit de dossiers bleek een mediane follow-up na MUS-resectie van 12 (range 2-66) maanden. 
Postoperatief had $61 \%$ van alle patiënten een toename van stressincontinentie (resectie partieel 39\% vs. compleet $73 \%$ ). Van alle vrouwen met incontinentie zag $19 \%$ af van aanvullende therapie door met name angst voor hernieuwde pijn.

\section{Conclusies}

Bij persisterende pijn zonder aantoonbare afwijkingen is (partiële) resectie van een MUS een goede optie met een significante daling van de VAS-score. Hierbij dient rekening te worden gehouden met een toename in incontinentie en een mogelijke hernieuwde behandelwens. Dit mag echter het bespreken van of verwijzen voor chirurgische resectie als alternatief van conservatieve behandeling niet belemmeren.

\section{MRI-geleide vs. systematische prostaat- biopten: voorspelling van de pathologische uitkomsten bij radicale prostatectomie}

\author{
G.D. Vadokas, L. Exterkate, J. de Baaij, H.J.E.J. Vrijhof, \\ J.P.M. Sedelaar, J.P. van Basten en D.M. Somford \\ Canisius Wilhelmina Ziekenhuis, Nijmegen
}

\section{Introductie}

De toepassing van MRI-geleide prostaatbiopten (MRI-GB's) heeft geleid tot een significante verbetering van de primaire diagnostiek bij prostaatkanker. Het is echter onduidelijk of aanvullende systematische prostaatbiopten (SB's) toegevoegde waarde hebben voor de diagnostiek of voor de operatieplanning van een radicale prostatectomie (RP's). Het doel van deze casecontrolstudie is de concordantie van drie biopsietechnieken (enkel SB's, enkel MRI-GB's of MRI-GB's in combinatie met SB) met de pathologie van het RP-preparaat te bepalen en vast te stellen of de biopsietechniek gerelateerd is aan de kans op positieve snijvlakken bij RP.

\section{Materiaal en methoden}

Vanaf september 2016 tot en met september 2018 ondergingen 463 opeenvolgende patiënten een RP in één hoogvolume prostaatkankercentrum en werden deze patiënten, afhankelijk van de biopsietechniek, ingedeeld in drie groepen (SB $v s$. MRI-GB vs. MRI-GB+SB's). Eindpunten waren de concordantie van de biopten en het RP-preparaat wat betreft Epstein-score en lateraliteit van de tumor (rechts/links/bilateraal). Middels een multivariabele logistische regressie is daarnaast getoetst of de biopsietechniek van invloed is op het risico op een positief snijvlak, waarbij PSA, cT-stadium, pT-stadium en Epstein-score in het RP-specimen als variabelen werden meegenomen.

\section{Resultaten}

Bij 222 patiënten werden enkel SB's afgenomen, bij 81 enkel MRI-GB's en bij 160 MRI-GB+SB's. De concordantie van de Epstein-score was 'gering' (kappa 0,2-0,4) voor enkel SB, en 'goed' (kappa > 0,6) voor enkel MRI-GB's en MRI-GB+SB's. De overeenstemming tussen biopten en lateraliteit van de tumor bij RP was 'gering' (kappa 0,2-0,4) voor alle drie de groepen. De multivariabele logistische regressie toonde dat bij patiënten die MRI-GB+SB's hadden ondergaan, de kans op positieve snijvlakken significant lager was dan bij patiënten die alleen MRI-GB ondergingen $(\mathrm{OR}=0,524 ; p<0,05)$.

\section{Conclusie}

MRI-GB's, alleen of in combinatie met SB's, hebben een hogere concordantie tussen de Epstein-score van de biopten en het RP-specimen dan SB alleen. Het combineren van SB's met MRI-GB's leidt tot een significant lagere kans op een positief snijvlak bij RP. 